\title{
A BARADLA-BARLANG RÉGÉSZETI KUTATÁSA
}

\author{
Holl Balázs* \\ A Baradla-barlang régészeti kutatástörténetét és a legújabb terepbejárások \\ eredményeként megismert régészeti topográfiáját mutatjuk be a tanulmányban. \\ Felhívjuk a figyelmet a barlangi kutatások problémáira és a dokumentálás \\ hiányosságaira.
}

Az aggteleki Baradla-barlang régészeti kutatása az elsők között indult meg az országban, régészetileg még sincs kellően dokumentálva a barlang. A tágabb környék barlangi és felszíni lelöhelyeihez viszonyítva jelentős lelőhelyről beszélhetünk. Szűkebb környezetben a barlang aggteleki bejárata elött ismerünk csak felszíni lelöhelyet, barlangi lelőhelyként pedig a Domica és az Ördög-lyuk (Certova diera) ismert. A Baradla-barlangrendszer hidrológiailag összefüggő egységet képez a szlovákiai Domica-barlangtól kezdve Jósvafőig, de mivel Jósvafő́n csak a legújabb korban létesítettek mesterséges bejáratot, a Domicával való összeköttetés pedig rendkívül nehezen járható (néhol víz alá bukó) folyosó, ezért a régészeti lelőhelyet nyugodtan köthetjük Aggtelekhez. A Domica barlang neolit lelőhelyével nyilvánvaló logikai kapcsolatban van, de két külön lelőhely hiszen a távolságuk 2 kilométer. A karsztfelszín erős eróziója még fontosabbá teszi a barlangi lelőhelyeket, mivel a felszínen szinte semmi sem marad meg. A leletek lemosódása után többnyire egy barlangban kötnek ki, és ez még nem jelent barlangi lelöhelyet. A kis területü barlangokban a rétegsor és a jelenségek könnyen megsemmisülnek nem kellően előkészített régészeti ásatás vagy barlangkutatás során. Ezzel szemben a Baradla-barlangban nagy felületeken még érintetlen rétegek és jelenségek találhatók.

A barlang az Aggteleki-karszt területén helyezkedik el, aggteleki bejárata közelében csak időszakos vízfolyások és tavak találhatók. Időszakosság alatt a szezonális és hosszabb távú változásokat is értjük, szárazabb-nedvesebb periódusok és a barlang feletti víznyelők eltömődése is közrejátszik abban, hogy néhány száz éves időszakokra teljesen más felszíni vízrajz jellemző. Ez nyilván nagymértékben befolyásolja a környék lakhatóságát. A barlangi vízfolyások ismereteink szerint stabilabb víznyerési lehetőséget jelentettek (1. kép).

\footnotetext{
* Holl Balázs. Magyar Nemzeti Múzeum, H-1370 Budapest, Pf. 364.
} 


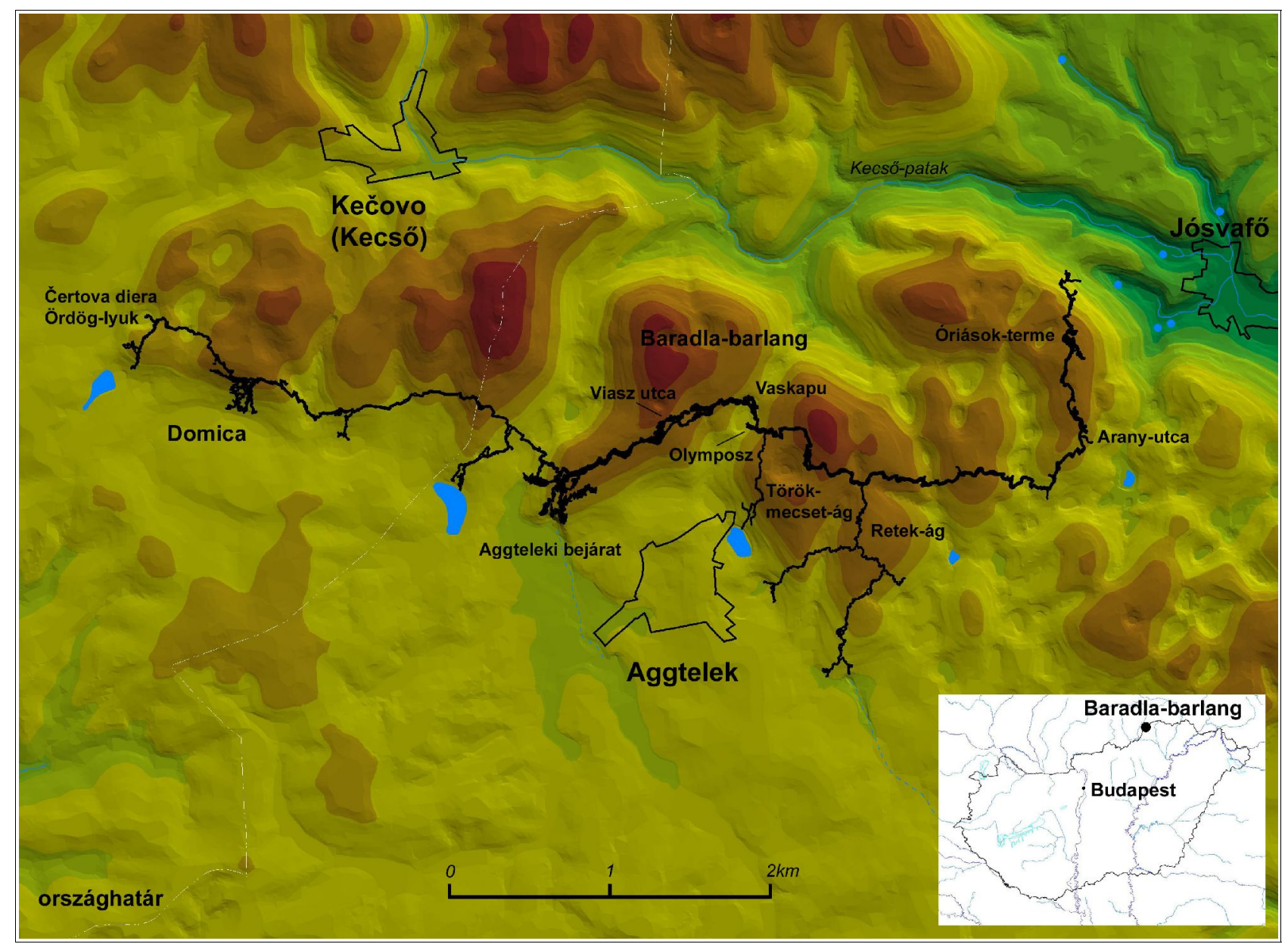

1. kép A Baradla barlang elhelyezkedése és szükebb környezete a rekonstruált vízrajzzal

Fig.1. The location and surroundings of the Baradla cave, with the reconstructed hydrogeology

\section{A Baradla-barlang régészeti kutatásának története}

A barlang kutatásának történetét legutóbb Kérdő Katalin ${ }^{1}$ majd Székely Kinga ${ }^{2}$ foglalta össze, de mivel munkájuk hiányos, ezért teljes összefoglalást kívánunk készíteni.

A barlang legelső leírásaiban is említenek régészeti leleteket, amiböl azt a következtetést vonhatjuk le, hogy különösebb kutatás nélkül is gyüjthetett bárki régészeti anyagot, mint ahogy ma is. Azt hogy ezt valaki tudományos feldolgozás céljára ezt a 19. század előtt megtette-e, annak írásos dokumentumát nem ismerjük, de kizárni sem tudjuk. Dokumentált terepbejárásról is csak 1952-től vannak adataink.

1856. augusztus 11 és 18. között Schmidl Adolf végzett ${ }^{3}$ a barlangban elöször dokumentált régészeti

1 KÉRDÖ 2000.

2 SZÉKely 2005.

3 SChmidL 1857. 
ásatást . Ö akkor tulajdonképpen őslénytani leleteket gyüjtött a barlang Paradicsom-ágában (ma Oszlopok-csarnoka). Nem talált régészeti leleteket, de az ásatását így is eredményesnek értékelte. A csontok és cseppkövek hasonlóságáról és a Csontház-terem emberi csontjairól idéz régebbi beszámolókat, melyből kitünik, és ezt meg is erősíti, hogy nem volt ideje behatóbban foglalkozni a hellyel. Pedig, mint vizsgálataink igazolták, az Oszlopok-csarnokáig nem terjednek ki a régészeti jelenségek a Csontházban pedig bőven vannak.

1867. augusztus 18-án a Magyar Orvosok és Természetvizsgálók Társasága (a Magyar Régészeti és Művészettörténeti Társulatnak is jogelődje) évi vándorgyülésük keretében ellátogattak az aggteleki barlangba, és ott mint a bejáratnál elhelyezett emléktábláról olvashatjuk "a tudomány fáklyájával vizsgálván" terepszemlét tartott.

1876. augusztus 24 és 26. között, újabb tíz esztendő múltán kezdte meg Nyáry Jenő híres ásatásait a barlangban. Segítője Thallóczy Lajos és Töttössy Béla volt. Ez a munka már nagyobb körültekintéssel indult, de általában elmondhatjuk hogy utána sem fordított figyelmet senki a barlang teljes átvizsgálására, így az ásatási helyszínek kiválasztása jórészt az elődök beszámolóján alapult. Az ásatás a Csontház-teremben és az odavezető folyosón volt. A folyosón - mivel azt teljes szélességben feltárta- rögzíthető az ásatás területe, és még ma is megfigyelhetök a megmaradt cseppkőkérgek, alattuk in situ emberi csontokkal, melyekről említést tesz. Nyáry még két ízben (1876. szeptemberének második felében és 1877. augusztus 16 és 18. között) végzett kutatást a barlangban, az utolsó időszak elején a barlang bejárata előtt is. Kutatását segítette Péchy Jenő, Thallóczy Lajos és Szukács Jenő. A helyszínek közé bekerült a Pitvar (logikusan a folyosó folytatásaként) és a Denevér-ág is. Ezen a szakaszon nem sikerült a kutatások helyszínét azonosítani. A kutatások folytatására 33 évet kell várni.

1910. szeptember 5. és október 5. között ugyan ezeket a helyeket kutatja Kadić Ottokár, Siegmuth Károly és Márton Lajos segítségével. Kadić leírásából ${ }^{4}$ a folyosó ásatási szelvényét kizárásos alapon nagy pontossággal lehet rekonstruálni. Erről az ásatásról őriz egy leltárt az MNM adattára 5 . Finger Béla 1911-es ásatásának csak a tényét tudjuk, 1912-es kutatásáról is csak annyival tudunk többet, hogy a Csontházban volt ${ }^{6}$.

1926. július 26-tól augusztus 22-ig Kadić Ottokár ásott Bogsch László és Kretzoi Miklós közremüködésével a Pitvar, a Denevér-ág és a Róka-ág területén ${ }^{7}$.

1929 decemberében Tompa Ferenc ásott a Róka-ágban, a Denevér-ágban és a Csontház-teremben.

\footnotetext{
4 KADIĆ 1911.

5 MNM Adattár 5.A.I, XVIII.274/1970.

6 Korek - Patay 1958.

7 KADIĆ 1933.
} 
Segítője Csalogovics József, aki ekkor talál egy későbronzkori aranykincs leletet. A leírásából ${ }^{8}$ a Csontház-teremre lehet ráismerni, de a pontos helyet nem lehetett meghatározni.

1937-ben Gallus Sándor ásott a Denevér-ágban. Ásatásáról csak egy felszínrajz maradt, amit méretarány nélkül több helyen közölnek. Az eredeti milliméter papír alapján a méretek tisztázhatók és a tájolás is valószínüsíthető. Gallus itt csak a kulturréteget tisztította meg, ami azt jelenti, hogy egy kb. 16 m2-es területen teljesen le kellett takarítania a felszínt. Ilyen terület a Denevér-ágban több is van.

1940-ben Mottl Mária ásott a Kistemplom (Hangverseny-terem), Nagytemplom (Fekete-terem), a Denevér-ág, és a Paradicsom (Oszlopok csarnoka) területeken. A Kistemplomban lévő ásatási helyszínt talán azonosíthatjuk az Óriáscseppkőről a Táncterem felé készült fényképen látható gödörrel ${ }^{9}$, és talán ez lehetett lefedve üveglappal aminek pusztulásáról Korek ír ásatási naplójában ${ }^{10}$. A Nagytemplomban megfigyelhető egy gödör, amelynek kitisztításakor tüzhely és karólyuk metszetek tárultak fel. Mivel erről a helyről más ásatást nem ismerünk, ezt azonosíthatjuk az ásatás egy (vagy egyik) gödrével. A Denevér-ági kutatóhelyről Vértes László tesz említést, ez alapján azonosíthatjuk. A Paradicsomban pedig a betonjárdákon kívül sehol nem találtunk egyértelműen ásatásra utaló nyomokat, tehát ez az ásatási terület azonosítatlan. Mottl ugyanekkor ásatott a Domicában is, ezért lenne érdekes, ha bővebb adatok állnának a rendelkezésünkre. Így csak annyit tudunk az eredményekről, hogy mivel paleolit rétegeket nem talált, nem tartotta fontosnak a későbbi korok leletanyagának említését.

1947-ben Vértes László kezdett foglalkozni a barlanggal, a Róka-ágban végzett ásatást. A pontos helyszínt itt sem tudjuk.

1952. augusztus 8-án Vértes kiszállás során agyagmintát gyüjtött a barlang meg nem nevezett részéröl ${ }^{11}$.

1953. december 14 és 19. között Vértes, Horusitzky Zoltán segítségével végzett ásatást a Denevérágban (Mottl-féle szelvény) és a Róka-barlang (Róka-ág) végén ${ }^{12}$. A Róka-ág végén megfigyelhető négy kis gödör, talán ezek lehetnek az ásatási területek. Az Óriás-terem felett a Meseországnál barlang-kutató ásást irányítottak úgy, hogy az esetlegesen előkerülő régészeti anyagot figyelemmel kísérhessék, sajnos minden eredmény nélkül.

1959. április 22-én és 23-án Jakucs László kérésére Vértes megszemlélte az Arany-utcát ${ }^{13}$, ahol

8 CSALOg 1976.

9 Ретнӧ 1966.

10 MNM Adattár XIV.147/1969.

11 MNM Adattár 51.Sz.I.

12 MNM Adattár 52.A.I.

13 MNM Adattár 140.A.II. 
agyagrétegek között erősen koptatott fosszilis csontokat és egy másik rétegben szintén víz által szállított cserepeket lehetett találni.

1959 november 27-én Jakucs kihívta Patek Erzsébetet, hogy megmutassa neki a Vaskapu környéki leleteket $^{14}$, és a Szultán-pamlaga fölötti részt. A vegyes leletek előkerülési helyét a leírások alapján tisztázni lehetett, de hitelességük az újabb kutatások alapján kétséges.

1960. december 6-10-ig Vértes László Salamon Ágnes, Patay Pál és Török Gyula segítségével hitelesítő ásatást végzett a Pitvarban ${ }^{15}$ végig bolygatott rétegben. A kézzel írt naplóban levő méretezett vázlat segítségével az ásatási szelvényt egész pontosan el lehet helyezni, így a szisztematikusan Csontház-teremként emlegetett helyszínt téves elnevezésként értékeljük. Itt érdemes megjegyezni, hogy a termek elnevezései időről időre változnak, így a helyszínek azonosítása sok kérdőjelet hordoz. Ugyanennek a kiszállásnak során megnézntek még több Jakucs által lelőhelynek vélt helyszínt (Óriások-terme, Szultán-pamlaga, Matyó-rojt, 790m, 2240m, 2660m), mindegyiket eredménytelenül. A lelőhelyek mindegyikére az volt jellemző, hogy Jakucs cserepeket, csontokat talált, de a leletek nem kerültek be semmilyen múzeumba, és a helyszínen Vértes kiszállásakor már nem volt semmi. $\mathrm{Mi}$ is ellenőriztük a vélt lelőhelyeket, de eredménytelenül.

1965. április 7-én Vértes László Stieber Józseffel környékbeli lelöhelyek helyszínelése közben megtekintette a villanyszerelési munkálatokat. Néhány cserepet mutattak neki.

1966. március 14-én Kemenczei Tibor és K. Végh Katalin a Fekete-teremben és a Csontházteremben végzett terepbejárást. A Fekete-teremben egy megbolygatott csontvázat tártak fel melléklet nélkül ${ }^{16}$.

1966. március 25-én Kemenczei Tibor ismét a barlangba ment, konstatálta hogy a Hangversenyteremben már befejezték a munkákat, de a Csontház-terem járdaépítése még hátra van ${ }^{17}$.

1967. április 6-án Patay Pál, 1969. február 4-én pedig T. Dobosi Viola végzett helyszíni szemlét a barlang előtt, majd 1969. április 21-május 15-ig Korek József végzett itt feltárást ${ }^{18}$. A feltárás során bebizonyosodott, hogy a barlang előtt neolit település volt temetkezésekkel.

1969. júliusában Kordos László végzett terepbejárást a Csontház-teremben, a Fekete-teremben és a Denevér-ágban.

1976. április 2 és 12. között Kordos László végzett rétegtani hitelesítő ásatásokat a Csontház-

14 PAтеK 1960; MNM Adattár I/1960/51.

15 MNM Adattár XI.247/1961.

16 HOM Adattár 16.

17 MNM Adattár XIII.138/1966.

18 KoreK 1970a; KoreK $1970 b$. 
teremben, a Róka-ágban és a Denevér-ágban ${ }^{19}$. Mindhárom helyszínen azonosíthatók a szelvények. Korek József 9-én meglátogatta az ásatást majd feldolgozta a régészeti anyagot ${ }^{20}$.

1981. március 10-én Simán Katalin a Róka-ágban végzett helyszínelést.

1981. júliusában Simán Katalin helyszínelt a barlangban ${ }^{21}$. A cikkben közölt Retek-ági túra valójában szóba sem jöhetett, a Róka-ág téves névmeghatározásáról lehetett szó ${ }^{22}$.

1988. február 4-én Hellebrandt Magdolna, Lovász Emese és Koós Judit szemlélte meg a barlangászok által feltárt réteget a Vaskapunál, de csak állati csontokat találtak.

1990-ben Hellebrandt Magdolna nézte végig a barlang aggteleki szakaszát a nagyszabású átalakítás előtt, de nem esett szó sehol az átalakítások régészeti felügyeletéről.

1994. május 25-én Hellebrandt Magdolna a barlang előtt végzett helyszínelést.

1994. március 30-án Rezi Kató Gábor helyszínelt a barlang elött.

1994. június 13-tól 24-ig Rezi Kató Gábor végzett leletmentő feltárást a barlang előtt.

2001. március 17-18-án több helyszíni szemlét követően Rezi Kató Gábor, Holl Balázs segítségével végzett leletmentő feltárást a Teknősbékánál a Róka-ág elött.

Ezt követően kezdődött meg az a rendszeres terepbejárás sorozat Rezi Kató Gábor vezetésével ami a jelen cikk alapját képezi. A terepbejárásban közre müködött Csengeri Piroska, Markó András, Marton Ádám és Holl Balázs.

\section{A Baradla-barlang régészeti topográfiája}

A barlang topográfiai leírásánál az első felmerülő kérdés hogy egy, vagy több lelőhelyről beszélhetünk-e. A régebbi leírások több lelőhelyről írnak, a barlang különböző ágait, termeit értve azok alatt. Ezt a szemléletet elvethetjük, mivel az aggteleki bejáratok környéke összefüggően lelöhelynek bizonyult, a többi lelet pedig nem köthető régészeti jelenséghez, így szórványként értékelhető csak. A barlangi helyek elnevezésénél a Baradla barlangkutató csoport által készített

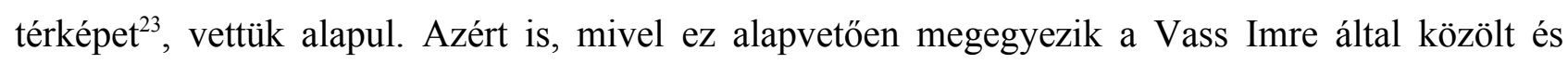
Nyáry Jenő ${ }^{24}$ által is használt elnevezésekkel, illetve jól nyomon követhetők a változások. A tévedéseket általában a szájhagyományként terjedő elnevezések rossz átvétele okozta (2. kép).

19 KordOs 1977; KoRdOs 1982.

20 MNM Adattár Ha97.VII.73.

21 SimÁn 1982.

22 Simán Katalin 2002-es szóbeli közlése.

23 Ország-VID-SzILÁGyi-VÉGH-GyuricZa 1989.

24 NYÁRY1881. 


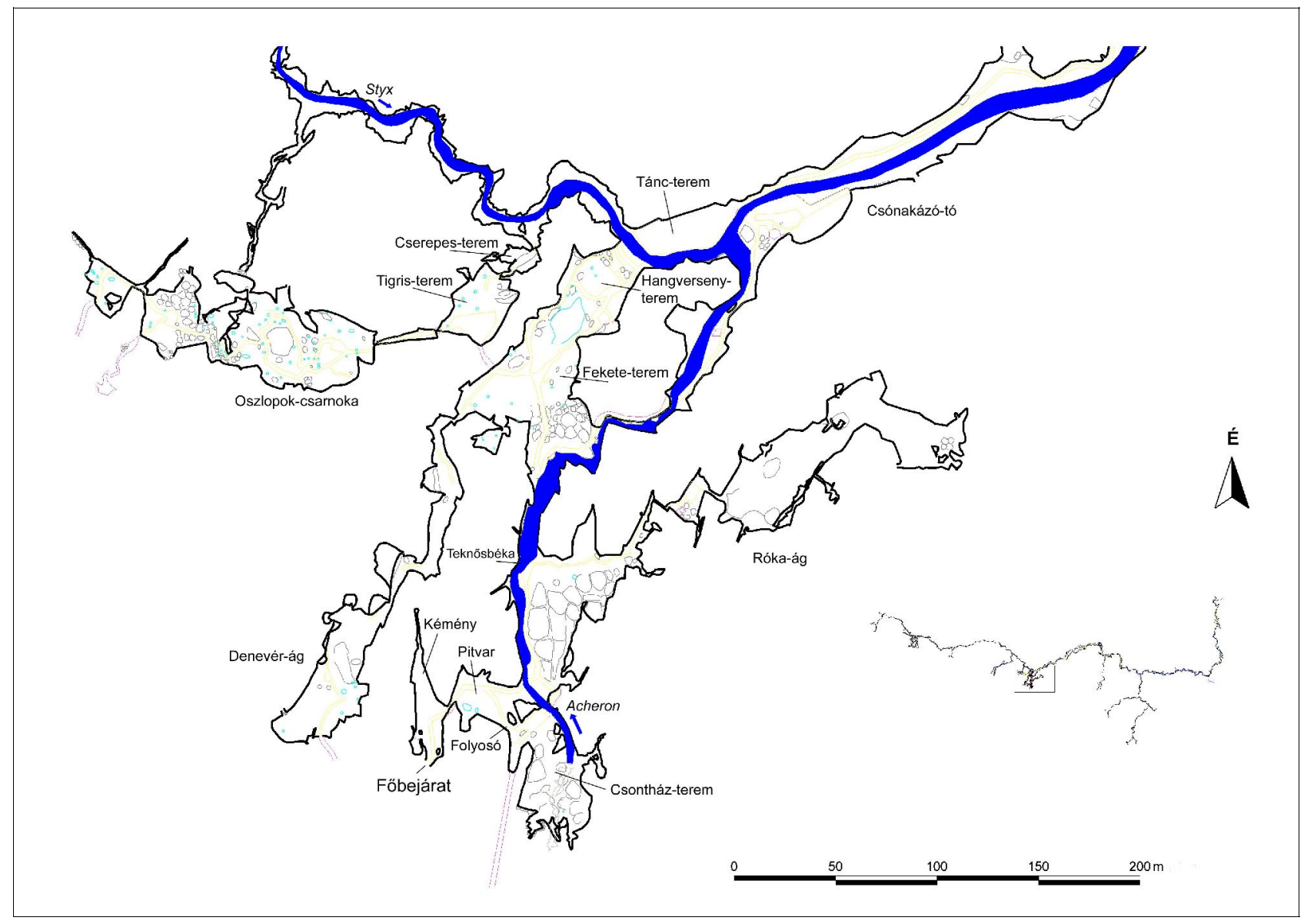

2. kép A Baradla-barlang aggteleki szakasza

Fig.2. The Aggtelek part of the Baradla Cave

\section{Bejárat elötti tér}

Az aggteleki bejárat külső környezete is régészeti lelöhely, ami szorosan kapcsolódik a barlanghoz. A különböző előkerült leletek alapján megállapítható, hogy szinte folyamatosan lakott volt, vagy mint egy jelentős hely előtereként folyamatosan látogatták. Tudjuk hogy a neolitikumban és a későbronzkorban itt település volt, de találtak itt kelta, császárkori és középkori leleteket is. A felszíni építmények (házalapok, cölöplyukak) alapján elmondhatjuk, hogy a barlang leleteinek fö korszakaiban (neolit, későbronzkor) a barlangot nem használták állandó szállásul, hiszen a barlang előtt volt a település. Maximum azt feltételezhetjük, hogy a település szegényebb lakossága nem tudott magának kint házat építeni, és a barlangban lakott folyamatosan, ahogy ezt még napjainkban is meg lehet figyelni más barlangoknál. Még ilyen esetben is sokszor a szabad ég alatt is kényelmesebb aludni, mint a barlangban.

\section{Bejárat}

A bejárat jellemzően a közlekedés célját szolgálta, így itt a leletek mellett nem várhatunk régészeti jelenségeket. Annál is inkább, mivel a folyamatosan csúszó kőtörmelék elfedett minden nyomot. Nem csak a természetes folyamatok, de az emberek is mozgatták a lejtőt. Az újkori leírásokból 
tudjuk, a járhatóság érdekében rendszeresen takarítani kellett a kőtörmeléket, nem lehetett ez máshogy régebben se. A modern tereprendezések és járdaépítés eltüntette a bejárat környékén a sziklafalról lehulló, a szikla előtt hegyet alkotó, és a bejáraton keresztül folyamatosan becsúszó omladékot. Pedig ez a kép nélkülözhetetlen a barlang korabeli viszonyainak érzékeltetéséhez. A bejárat nem volt se tágas, se világos. A barlang nem egy tipikus lakóbarlang, inkább kényelmetlen volt a ki-be járás, és azonnal félhomály fogadta a betérőket. Kivételt képezett az a délutáni egy-két óra, amikor a nap mélyen besüt a barlang bejáratán, megvilágítva a bejárati szakaszt, egyben elvakítva a kifelé jövőt. Ezen a szakaszon a modern áthalmozás miatt kevés leletet találtunk. Érdekesebb a bejárattól balra elhelyezkedő fülke, amire 1996-ban Szenthe István hívta fel a figyelmünket. Itt még teljes magasságban megvan a bejárati szakaszba becsúszó, rétegzett kitöltés, valamint becseppkövesedett csontok is találhatók. Mivel ez a rész már kiesik a közlekedési útból, és az eltömődése is elég idős, itt már feltételezhetjük hogy valamilyen funkciója volt. A modern korban fallal és ajtóval választották le, ami feltételezi hogy teljesen kitakarították a teret. Mégis elég nagy mennyiségü leletet lehetett benne találni. A törmelék lejtő folytatásában fokozatosan egyre több a lelet.

\section{Kémény}

A törmeléklejtő kifut egy vízszintes agyagos felszínre, ahol a felszínen sok cserepet, csontot és bolygatott részen hamus tüzelésnyomokat lehet találni. A területet kéménynek hívják, a bal oldali fal mentén magasba szökő hasadékról. Hogy valójában elvezeti-e a füstöt, ezzel alkalmassá teszi a területet tartós nagy tüzelésre, azt nem tudjuk. A hátsó hasadékban időszakosan vizet lehet találni. Sajnos a területen láthatólag több rablóásatás ${ }^{25}$ is megbolygatta az egyébként ásatásra még alkalmas felszínt. A kidobált emberi csontokból temetkezésre lehet következtetni. Ez a barlangban az első településre alkalmas felszín. Hogy miért kerülték el az ásatók, azt nem lehet tudni. Talán rossz világítás esetén nem feltűnő vagy úgy gondolták, hogy túl közel van a bejárathoz. Pedig a folyamatosan terjeszkedő törmelék lejtő egyben védelmet is jelent az alatta levő régészeti jelenségeknek.

Jobb oldalon a továbbvezető járatot többször tágították ás az alját teljes szélességben kitölti a beton járda, így itt sem leleteket sem régészeti jelenségeket nem lehet már találni. Lényeges tény, hogy az eredeti állapotában szük átjáró után sokkal inkább lehetett érzékelni a következő terem kiszélesedését mint most.

\section{Pitvar}

A következő terem neve Pitvar, vagy régebben Nagy Pitvar, (hogy volt-e Kis Pitvar vagy sem, nem

25 Szóbeli tájékoztatás szerint 1988 nyarán miskolci barlangászok bontottak meg temetkezést, ahonnan koponyát vittek el. 
tudjuk). A túravezetők ezt a termet nevezik Csontháznak, mivel úgy tudják, hogy itt tárta fel Nyáry Jenő a temetkezéseket. Vértes László is Csontházként nevezi jelentésében ${ }^{26}$, pedig ő is részt vett abban a bizottságban, ami a barlang régi elnevezéseit megváltoztatta. A nevek csúszása a barlangon belül többször is előfordul, de ez egyértelmüen tévedés. Nyáry könyvéből a leírásokból és a temetkezési folyosó metszetrajzából egyértelműen kiderül, hogy ő is a Vass Imre térképét vette alapul a nevek tekintetében, és Pitvarként kell továbbra is neveznünk.

Többen is úgy ítélték, hogy a Pitvar teljes területe fel lett forgatva, pedig itt olyan cseppkőlefolyás található, ami egyértelmüen elfed rétegeket. A Pitvar ásatásait Nyáry Jenő kezdte 1876-ban és Vértes László fejezte be 1960-ban. Ez alatt az időszak alatt legalább öt ásatás zajlott a területen. Valószínűleg mindenki a bal oldali részre koncentrált, ahol kényelmesen fel lehet egyenesedni, így maradhatott a jobb oldali alacsony területen ez a cseppkő bekérgezés, alatta feltehetően ugyanazokkal a rétegekkel, amit hasonló cseppkő kéreg alól néhány méterre ettől Nyáry feltárt²7.

A Pitvar eredet felszínét csak itt ismerjük, a bal oldalon és középen az ásatások, ásatások utáni tereprendezések és a járdaépítések teljesen eltüntették. Feltételezhetjük, hogy a Kéményhez hasonlóan sima agyagfelszín volt beágyazódott nagyobb és felszínen fekvő kisebb kövekkel. A cseppkő képződmények csak a fal mentén jelentek meg, néhány kisebb állócseppkővel a terem belsejében. A kulturréteg vastagságáról nem tudunk biztosat, de az agyag, kőtörmelék és homok alatta több mint 4 méter, amit Kadić 1910-es ásatása folyamán tárt fel ${ }^{28}$. Kadić 1 méter vastag kulturréteget említ tűzhely maradványokkal, de biztosan át kellett vágnia a Nyáry-féle ásatások által bolygatott felszínt is, ahol a rétegek már keveredtek.

A pitvart jobbra elhagyva a Csontház terembe jutunk, a bal oldali járat pedig az Acheron patakon keresztül egy alacsony folyosóban vezet tovább. A Csontház eredetileg zsákutca volt, de így is ez a pont az, ahol több járat összefut - így ha volt is település, mindenképpen számolni kell a közlekedési utakkal.

\section{Temetkezési-folyosó}

Nyáry Jenő első ásatása a Pitvart a Csontház teremmel összekötő folyosón és a Csontház teremben volt. A folyosót teljes keresztmetszetében feltárta. A temetkezésekről a területet Temetkezési Folyosóként nevezi el. A publikációban ${ }^{29}$ közölt metszetrajzok segítségével pontosan azonosítható a terület, ahol a fal mentén még in situ rétegeket lehet találni az eredeti cseppkő kérgek maradványai

26 MNM Adattár XI.247/1961.

27 NYÁRY 1881, 74.o.: “A „Nagy-pitvar” különböző helyein a csepegőkőréteg alatt folytatván az ásatást, szintén emberi vázakra akadtunk."

28 KADIĆ 1911.

29 NYÁRY 1881, 158-159.o. 
alatt. A terület nem határolódik el a Pitvartól, a folyamatosan összeszükülő járat csak a Csontház terembe érve szélesedik ki hirtelen. A terület maximum 20-30 cm-rel lehetett magasabb, így eredeti képe nagyon hasonlít a mostani megjelenéséhez. A talaj itt is vízszintes és agyagos lehetett, az oldalfalak mentén cseppkő kéreggel.

\section{Csontház-terem}

A Csontház terem elnevezése ma megint problémás, a túravezetők most az Acheron forrásának nevezik a helyet. Raisz Keresztély Mausoleumnak nevezte ${ }^{30}$ az itt található csontvázak után, Vass Imre is említi ezeket könyvében ${ }^{31}$.

A terem alsó részén ma lebetonozott járda van. Itt lehetett mélyebb, ásatásra alkalmas agyagos felszín. Nyáry legalább $2 \mathrm{~m}$ vastag kulturréteget említ ${ }^{32}$. Feljebb néhány gödör sekélyebb ásatások maradványa lehet. Itt Nyáry is ásott, a kulturréteg alatt cseppkövesedett rétegekben és alatta is talált leleteket és csontokat. A terem hátsó részén pedig csak a nagy kőtömbök tetején, vagy a cseppkő kéreg alatt lehet leleteket találni. A teremhez kapcsolódnak a legfontosabb leletek és jelenségek. Nyáry másfél méter magas kőrakásban emberi csontvázat talált ${ }^{33}$, Tompa Ferenc egy szentélyt tárt fel és bronz kincsleletet, Csalog József pedig valószínüleg itt találta az elrejtett bronzkori aranykincset. Ma is látható itt néhány jó állapotban lévő cseppkövel begérgezett neolit edény, és itt a legnagyobb a felszíni leletsürüség. A legutóbbi ásatások ${ }^{34}$ itt nem hoztak új eredményeket, de bizonyították hogy a cseppkő lefolyások alatt vannak még bolygatatlan neolit rétegek.

Jelenleg a járda egy hídon és egy mesterségesen bővített járaton keresztül hagyja el a Csontháztermet, így a látogatóknak nem kell visszafordulni a Pitvarba. Régebben az átjárás itt csak a patakon keresztül volt lehetséges, amit a Pitvarból bal oldalon nyíló járaton keresztül lehetett kikerülni. Itt is át kell haladni a patakon, de valószínűleg sokkal kényelmesebben tehették ezt, mivel évszázadokon keresztül erre haladt a túra útvonal. Az egész megkerülendő rész egy kőtörmelékkel kitöltött alacsonyra lelógó mennyezetü járat, aminek nincsenek határozott kontúrjai, méreteit az ásatások bolygatásai jelentősen befolyásolják. Nehéz rekonstruálni mikor milyen lehetett a terep, hiszen a feltöltődést és a cseppkő bekérgezéseket az ásatások és a járdaépítések teljesen átrendezték.

Acheron-ág

A tovább vezető út az Acheron patak jobb partján nagy kőtömbök alatt vezet. A patakban az iszapos

30 RAISZ 1807.

31 VASS 1831.

32 NYÁRY 1881, 22.o.: "Fölül mintegy másfél méter magasságban culturföldre akadtunk. E föld felületét 0.31 méter iszap födte. Alatta fekete könnyü állományú föld 0.63 méternyi magasságban volt, melyben cserépdarabok, bronzkori tárgyak és állatcsontok fordultak elö."

33 NYÁRY 1881, 27.o.

34 Kordos 1977. 
rétegek nem tudjuk mit őriztek meg. A patak partját most teljes egészében a beton járda fedi le. A nagy kőtömbök közötti hasadékokban szép számmal lehet cserepet és csontot gyüjteni, ami lehet behullott is, de biztosan járták ezeket a helyeket az őskorban is. A nagy kötömbök lapos felületén viszont minden jel szerint volt folyamatos tevékenység, amit a leletek nagy száma és a vastag (1-2 $\mathrm{cm}$ ) fekete réteg jelez. A tüzelésnek itt közvetlen bizonyítékát (átégett agyag) nem lehet találni, így nem kizárható, hogy nem tüzelésből, hanem csak elszenesedett növényi anyag törmelékéből áll a fekete réteg, ahogy azt a Csontház-terem mélyebb rétegeiről Nyáry megállapította ${ }^{35}$. A széna kiváló fekhely a barlangban, de nedves időszakban gyors rothadása szükségessé teszi rendszeres megújítását. A kőtömbök a Róka-ág bejáratánál érnek véget. A leletek itt is, mint a barlang más részein, barlangászok által kis kupacokba rakva is találhatók. Ez nem jelenti azt, hogy máshonnan származnának, egyszerűen csak a lelkes amatőr gyüjtögetők nem találták érdemesnek elvinni a néhány négyzetméternyi területről összeszedett darabokat. Sajnos amit viszont elvittek, az a szebb, épebb, esetleg egész edénnyé összeállítható töredékek voltak.

\section{Teknösbéka}

A teknősbéka (régebben Mózes oltára) előtti lapos területet ma szintén betonjárda fedi el, de hátrébb a kapcsolószekrényeknél meg lehet találni a bolygatatlan felszínt. Itt nagy vízszintes területen rengeteg leletet lehet a felszínen találni, és Rezi Kató Gábor 2001-es leletmentése nyomán tudjuk, hogy legalább $15 \mathrm{~cm}$ vastag kulturréteg fekszik az átégett felszín alatt. A jelenleg tárolóhelyként használt területre Stieber József hívta fel a figyelmünket. A lekopott felületen jól ki lehetett venni a tüzhely vöröses foltját. A területet valószínüleg minden korban használták, így a tüzhelyfolt egyelőre korhoz nem köthető. Az egész terület a patakig hasonló, megtelepedésre kiválóan alkalmas lehetett. Talán itt kereshetjük a Tompa Ferenc által feltárt temetkezés helyét. A felette levő sziklákról jól be lehetett látni a területet, ugyan úgy, mint a Csontház felső részéről az alsót. Különbséget a mostani klímaviszonyok között nem találni, de feltételezhető, hogy a nyitott bejárat esetén a barlang hidegpontja (ahová a téli hideg levegő még beáramlik) a Csontházban lehetett ${ }^{36}$. A teknősbékánál az út ismét kétfelé ágazik, jobbra a Róka-ág, balra a továbbvezető járat. Róka-ág

A Róka-ág elején, elhagyva a nagy omladékot találjuk Kordos László 1976-os ásatási szelvényét, amelynek oldalán néhány karó lyuk nyomát és vékony kulturrétegeket figyelhetünk meg.

A tovább indulva elöször egy keskeny járatban, majd derékszögben jobbra fordulva egy még keskenyebb hasadékon keresztül jutunk tovább. Ezt a hasadékot a barlangbiológiai laboratórium létesítése miatt vasráccsal zárták le. A tágítási nyomokból kitünik, régebben még alacsonyabb és

35 NYÁRY 1881, 24.o.

36 NYÁRY 1881, 21-22.o. Közöl néhány régebbi hömérséklet mérés eredményét. 
keskenyebb lehetett. Ez nem szegte kedvét az őskori látogatóknak, mivel az első teremben (barlangbiológiai laboratórium) jelentős mennyiségü leletet találni. A felszín itt is lebetonozott, és újabban teljesen kitakarították. A még fellelhető kulturréteg foltok mellett karónyomok is vannak. A tovább vezető szükület megint nem bizonyult legyőzhetetlennek, utána a Róka-ág végén levő terem elején foltokban összetartozó cserepeket és becseppkövesedett csontokat találhatunk. Innentől a terep eredetinek mondható, nagy kövek között lapos részeken faszenes területekkel. A termet csak a ház nagyságú cseppköves kőtömbök választják el a hátsó sima résztől. Mégis, a leletek fokozatosan elfogynak ami a járat hátsó részének őskori használatát kizárja. Itt bejárat semmiképpen nem lehetett. Az egyik neolit edény határozottan vízgyüjtés céljára lett betéve kövek alá, becseppkövesedve ma is ott áll. A terem hátsó részén sima vízszintes agyagfelszín található, nyilvánvalóan pangó víz hozhatta létre. Szemtanuk beszámolója szerint még a 60 -as években is állt víz itt. A területet csak négy apró kutató gödör bolygatta meg, benne a meszes agyag csíkok a víz által lerakott rétegein kívül mást nem láthatunk. A gödröket azonosíthatjuk Vértes 1953-as ásatásával ${ }^{37}$, vagy geológiai mintavételezéssel is. A leletek fokozatos elfogyását azzal magyarázhatjuk, hogy ide csak vízért jöttek be elsősorban a neolitikumban.

Visszatérve a Teknősbékához, utunkat az Acheron medrében folytathatjuk. Jelenleg magasan felépített betonjárdán haladhatunk, de nyilván ez nem mértékadó. A járat száraz időben, amikor az Acheron elapadt, biztosan járható volt mindig, mivel egy régi szerző sem említ nehézségeket a túra e szakasza kapcsán. A patakmeder rétegsorát nem ismerjük, az oldalt álló sziklákon is csak néhány szórvány cserepet gyüjtöttünk.

A patakmeder jobbra fordulva folytatódik, de mivel a mélyebb gödrökben pangó víz csak a legszárazabb időben teszi lehetővé a továbbjutást, a régi túra útvonal balra a Fekete-teremben folytatódott. Most egy mesterséges járat bővítésen keresztül végig lehet menni a patak mellett, de leleteket sehol sem lehet találni.

\section{Fekete-terem}

A Fekete-terem (régebben Nagy templom) a régészeti leletekben gazdag szakasz legnagyobb terme. A teremben fut össze a Denevér-ági járat, az Acheron-ág ahonnan mi is érkezünk és a Hangversenyterem (Kis templom) felöli két járat. A terem Acheron-patak felőli oldalán nagy kőtömbök vannak, de a felső részén lapos, többnyire cseppköves terület található. A területet itt is erôsen megbolygatták járda és világítás építéssel. A reflektorok elhelyezéséhez cseppkőböl falakat is építettek, a kábeleket pedig megpróbálták elásni. Az Acheron felől felvezető járatot pedig

37 VÉRTES 1954: "Vizsgálataink némi eredménnyel jártak a »Rókabarlang« legvégső szakszán, ahol vörös agyagkitöltésben barlangi medvecsontokat találtunk, anélkül azonban, hogy az ember hajdani ottlétére bizonyítékot kaptunk volna." 
besüllyesztették az agyagba. Itt metszetben karónyomok láthatók, és a felszínen megfigyelhető a vékony kulturréteg. A terem közepén a járdától kb. 2 méterre, egy gödör metszetfalában tüzhelyet és karólyukakat (3. kép) figyelhetünk meg. Feltételezzük, ez egy régészeti kutató árok, melyet még Mottl Mária mélyített 1940-ben. A cseppkőlefolyásokban több csont és cserép van beágyazódva. A terem méreténél fogva alkalmas tüzelésre, tartós táborozásra, még állatok elhelyezésére is el lehet rekeszteni néhány sarkot. Az egyik ilyen rész az un. Bagolyvár: a cseppkövek között kisebb lapos terület van. A terem cseppköves falában mesterségesen tágított, kúszva járható folyosón keresztül egy kisebb üregbe jutunk. Az üreg semmilyen leírásban nem szerepel, valószínűleg nem rég óta ismert. Benne csak kevés állatcsontot találtunk. A Fekete terem egyes pontjain feltünően sok leletet lehet találni, máshol viszont teljesen kitakarították a többszöri építkezések, tereprendezések.

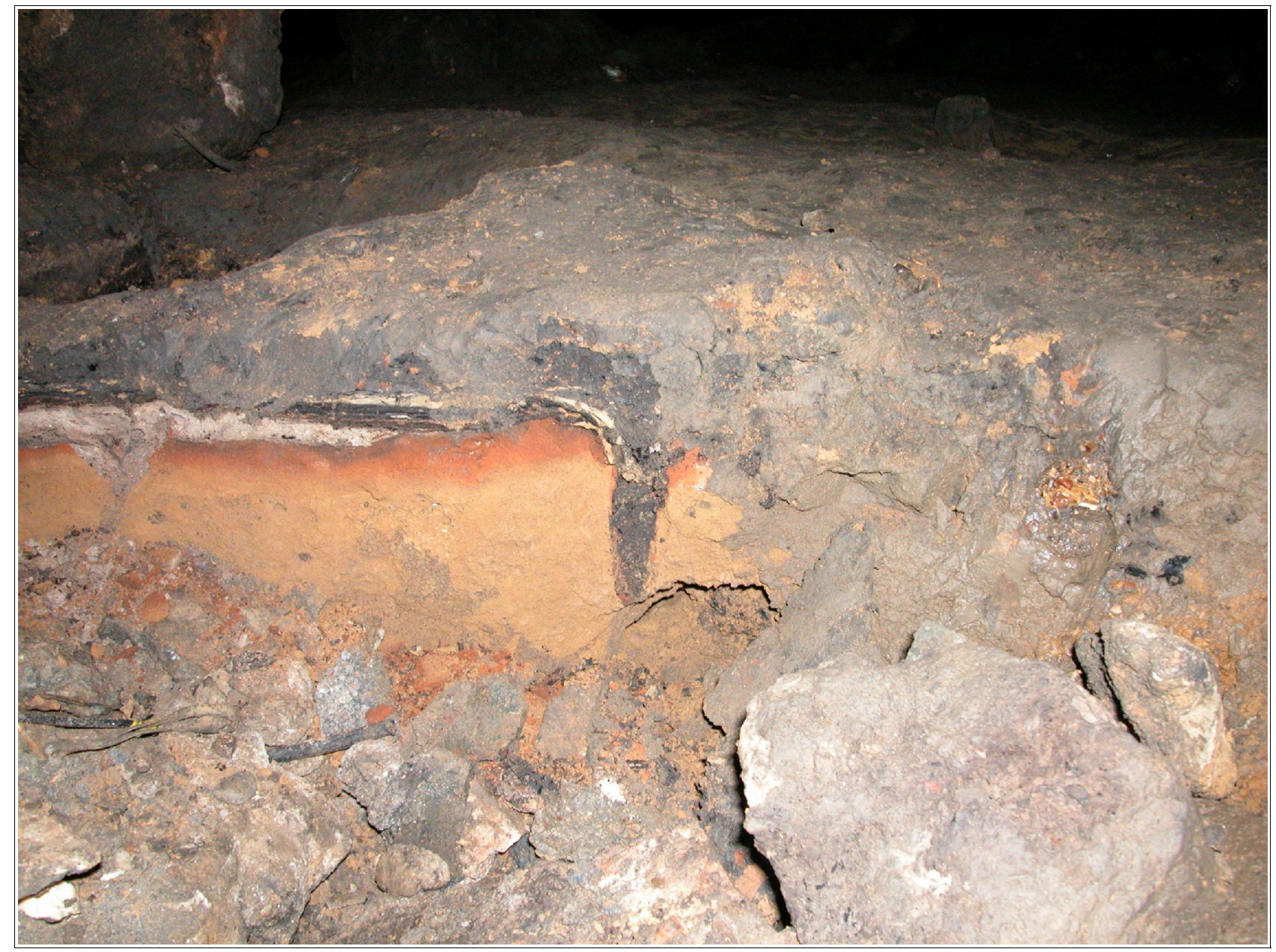

3. kép Tüzhely és karólyuk metszete a Fekete-teremben

Fig.3. Cross-section of a fireplace and a peg-hole in the Fekete-room

Tovább menni a Hangverseny terembe az óriáscseppkő mindkét oldalán lehetséges.

Hangverseny-terem

A Hangverseny terem (régebben Kis templom) az egyike a barlang legjobban feltárt, ugyanakkor 
legkevésbé dokumentált termeinek. A terem felső részén az Óriáscseppkő oldalában egy cseppkő medencében csontvázat találtunk hosszúcsontok és koponya nélkül, de anatómiai rendben. A csontváz mellett egy összeállítható neolit tál volt. A terem közepéig több helyen feltárt kulturréteg található, itt sok cserepet gyüjtöttünk, de a terem alsó részét teljesen elbontották a színpad kialakításával. A terem közepén feltételezzük azt az üveglappal lefedett karólyukas, tüzhelyes feltárást, ${ }^{38}$ amelynek pusztulását Korek említi ásatási naplójában. ${ }^{39}$ A feltárás valószínűleg Mottl nevéhez köthető, de semmi dokumentációját nem találtuk. Az elbontott agyagfelszín határán több karólyuk, tüzhelyfolt, kulturréteg rajzolódik ki, ebből következtethetünk a teljes felületet eredetileg borító régészeti jelenségekre. Mivel a terem alján folyik a Styx, de a meredek felszín még a legnagyobb áradásoktól is megvédte a terem felső részeit, kiválóan alkalmas lehetett megtelepedésre.

Nem tudjuk, hogy nézhetett ki eredetileg a Styx medre, mivel mindkét partját kiépítették, de biztos hogy át lehetett kelni rajta, a tovább menő út a patak másik oldalán van.

Tánc-terem

A termet a Styx választja el a Hangverseny-teremtől. Nevét az itt rendezett mulatságokról kapta. Feltételezhetjük, hogy teljes lebetonozása előtt is nagy lapos száraz részek voltak itt, ami alkalmas táncparkettnek. A régi fényképen viszont törmelék dombokat is láthatunk. Sajnos a teljes átalakítás - nézőtér kialakítása, csónakázó tó kikötő kialakítása - teljesen alkalmatlanná teszi a régészeti megfigyelésre. Esetleg eltemetve maradtak még jelenségeket, de ehhez fel kellene bontani az egész termet borító betont.

A fóágban továbbvezető utat később tárgyaljuk

A Styx bal partján folyás iránnyal szembe haladva juthatunk be a Styx-ágba, majd újra átkelve a patakon a Paradicsom ág felé mehetünk egy szük folyosón.

\section{Cserepes-terem}

A folyosót mesterségesen mélyítették a túra útvonal számára, az első kiszélesedését a Baradla barlangkutató csoport tagjai Cserepes-teremnek nevezik az itt található feltünően sok edény töredékről. Mivel eredeti állapotában a folyosó csak négykézláb járható, néhol még fel sem lehet ülni benne, rejtélyes az itt megfigyelhető karólyukak, tüzhelyek funkciója. A kerámia töredékek alapján a neolitikumban használták ezt a részt.

Tovább menve egy cseppkövek közti meredek lépcsőn beérünk a Tigris-terembe.

\section{Tigris-terem}

A terem alját félig beton járda, félig cseppkő bekérgezés fedi. A köztük lévő kevés agyagos

38 VÉRTES 1952.

39 Korek ásatási napló 1969, MNM Adattár XIV.147/1969. 
felszínen viszont kulturréteg nyomai figyelhetők meg. A rétegből és a cseppkövek közül gyüjtött cserép föként későbronzkori, de a kevés neolit anyag bizonyítja, hogy már akkor is ismert volt. A Fekete-teremből a Tigris-terembe vágott mesterséges átjáró jelentősen megváltoztatja a terem jellegét, egyrészt a bejárhatóság, másrészt a szintkiegyenlítő betonozás miatt. Régen ez lehetett az utolsó pontja a járatnak, mivel a továbbiakban lelet nem kerül elő. Most a mesterséges kijárat felé tovább lehet menni. A tovább vezető folyosó szintsüllyesztésének oldalában kormos réteg figyelhető meg leletanyag nélkül, ami fokozatosan elvékonyodik a teremtől távolodva. Feltételezhetjük, hogy a tüzelés füstjét vitte erre a huzat, és ez okozza a lerakódást.

Vass Imre leírásában ${ }^{40}$ részletesen közli a továbbmenő járatot, egészen az utolsó teremig, ahol fekete korsó darabokat említ. Részletesen átkutattuk az egész ágat, és régészeti leleteket nem találtunk csak egy csont darabot, és az Oszlopok-csarnokában egy másodlagos helyzetben lerakott edénytöredéket. Schmidl feltárásakor ${ }^{41}$ is csak medve csontokat talált itt, bár az ásatás helyét nem sikerült azonosítanunk. Ebből azt a következtetést vontuk le, hogy a továbbmenő járat kibontása valamikor az újkorban történhetett, a leletek pedig nem régészeti korból származhattak. Ez a feltételezés a barlang jósvafői szakaszának fekete cserepeit is más jelentőséggel ruházza fel.

\section{Denevér-ág}

A barlang másik természetes aggteleki bejáratának feltárásáról szóló leírásból ${ }^{42}$ tudjuk, hogy az eltömődött rész kibontása nem okozott nagy nehézséget. Joggal feltételezhetjük, és a nagyszámú lelet is ezt bizonyítja, hogy régebben nyitott volt, csak a középkor elött tömődött el. Ez a bejárat nagyon hasonlít a főbejáratra, de még meredekebb törmelék lejtővel kezdődik. Már a törmelék közt is sok lelet van, de lejjebb a lejtő végénél tüzhelyet is feltártak. A teremben feltünően sok állat karmolás nyom van a sziklákon és cseppköveken, de emberi kéztől származó jelet nem lehet azonosítani. A termet hatalmas cseppkő választja ketté, utána már vízszintes járat következik. Itt a második kiszélesedés közepén hatalmas beásás látható. Mivel többen is ásattak a barlang ezen szakaszán pontosabb helymegjelölés nélkül, nem lehet eldönteni melyik kutatóhoz köthető. A sziklák mögötti védett részen sok leletet lehetett találni a felszínen.

A terem utáni kanyargós folyosó járda építésénél átvágták a kulturréteget, és itt tanulmányozhatjuk legjobban annak sajátosságait. A sárga köves-agyagos törmelék tetején éles vonalban fekete faszenes cserepekkel teli 2-10 cm vastag kulturréteg fekszik, ami rétegződés nélkül tartalmazza a neolitikumtól kezdve a legújabb korig a leleteket. A kulturrétegből karólyukak nyúlnak az altalajba. A cserepek mérete néhol meghaladja a kulturréteg teljes vastagságát, ezért korhatározásra

40 VASS 1831.

41 Schmidd 1857.

42 Kessler 1934. 
alkalmatlanok. Nagy szerencse, és precíz metszetek kellenek a karólyukak réteghez vagy leletekhez rendeléséhez. Csak olyan esetekben lehet biztosan elválasztani rétegeket, ha valami omlás közbeékelődik. Legkisebb felszín bolygatás is tönkre teszi a réteget és eltünteti a jelenségeket.

A folyosó felszínét néhol feltöltéssel, néhol bevágással tették vízszintessé. A következő métereken láthatjuk, hogy az eredeti felszín lenyomata a falon majd két méter magasságig nyomon követhető. A kanyar után viszont kb. fél méteres feltöltés takarja el az eredeti felszínt.

A folyosó derékszögü kanyarjában egy ásatási szelvény, a szelvény falában rétegek és karólyukak találhatók. A rétegsornak csak a legfelső rétege tartalmaz leleteket, az alsóbb rétegek csak geológiai információt hordoznak, bár Vértes László ebben a szelvényben található faszén darabokra alapozva feltételezte a jégkori ember jelenlétét a barlangban.

A folyosó kiszélesedésénél egy hatalmas kőtömb mögött még található bolygatatlan felszín, a többi részen a járda feltöltése alatt lehet remélni régészeti jelenségeket, ahol szintsüllyesztés volt, ott megsemmisültek.

A folyosó Fekete-termi becsatlakozásánál a falon medve karmolások vannak.

A Fekete-termen és a Hangverseny-termen áthaladva újra elérjük a Tánc-termet. Ez már tulajdonképpen a barlang fö-ága, itt egyesül a Styx és az Acheron patak. A két patak találkozása utáni szakaszon mesterségesen hozták létre a Csónakázó-tavat, magasított beton járdákkal, kikötővel és zsilipekkel.

\section{Csónakázó-tó}

A tó helyén a föág eredeti képének rekonstruálásakor a további, kiépítetlen szakaszokat vehetjük alapul. A patak sóderes, kavicsos medre kitölti az egész járat szélességét, csak ahol az áramlási viszonyok ezt lehetővé teszik vagy omladékok töltik fel a járatot, alakulnak ki agyagos dombok, melyek csak a legnagyobb árvizek esetén kerülnek víz alá. Ezeken a területeken lehet reményünk leletek vagy objektumok megmaradására. A patakmederben az évenkénti áradások elmosnak minden nyomot.

Ezeket a szárazulatokat vizsgáltuk végig az egész föágban, különös tekintettel azokra a helyekre, ahonnan régebben leleteket közöltek.

Négy ponton találtunk leleteket, amelyek lehetnek akár másodlagos helyzetüek is, mivel települési jelenség egyáltalán nem volt megfigyelhető. Kitünik közülük az a leletegyüttes, ami mind megtalálási helye miatt (a meder járdával ellenkező oldalán, egy csak kúszva járható sáros, üregben), mind kora miatt érdekes. A középkori kerámia csak a barlang közvetlen bejárati szakaszára jellemző, beljebb sehol máshol nem találtuk nyomát. Itt viszont nagyszámú töredék került elő egy helyen.

Tovább haladva a leletek száma, és előkerülési körülményeinek a hitelessége is csökken, azt kell 
mondanunk, hogy a barlang belső részeinek használatáról nincs semmiféle hiteles adatunk. régészeti korból származó jelenséget sehol nem sikerült megfigyelni.

\section{További területek a barlangban}

Végig járva az egész barlangot, megvizsgáltunk minden számba jöhető helyet, ahol leletek egyáltalán megmaradhattak, különös figyelemmel azokra a helyekre, ahonnan leleteket jelentettek. Ezeket sorra véve próbáljuk összeállítani a barlang további képét.

\section{Omladék-terem $(790 m)^{43}$}

A területet átvizsgálva nem találtunk leleteket. A koromcsíkos cseppkövek arra mutatnak, hogy a füst rendszeresen eljutott idáig, de ez lehetett akár a Hangverseny-teremből származó is.

Viasz utca

Pávai-Vajna Ferenc geológus mutatta a területet Vérteséknek ${ }^{44}$, hogy itt talált cserepet. A területet átvizsgálva egy erősen koptatott cserép darabot találtunk, amely egy kürtőn keresztül mosódhatott be a barlangba.

\section{Vaskapu}

A Patek Erzsébet ${ }^{45}$ által közölt helyen és annak tágabb körzetében leletet egyáltalán nem találtunk. A hely mindenféle emberi tevékenységre alkalmatlan meredek omladék.

\section{Szultán pamlaga (Olymposz)}

Jakucs László bejelentése alapján Patek Erzsébet helyszínelte a területet. Most ezen a helyen semmilyen leletet vagy jelenséget nem lehet látni, a feltételezett táborhely ${ }^{46}$ csak korlátozottan alkalmas emberi pihenésre, tüzelésnek, kulturrétegnek nyoma nincs ${ }^{47}$. Néhány jelenkori virágcserép darab a barlangászokhoz köthető.

\section{Törökmecset-ág}

A járat alkalmatlan régészeti kutatásra, de a Vértes által említett ${ }^{48}$ bemosott csontokat - bár mi nem

43 Vértes László a kiszállási jelentésében ezekre a méter adatokra hivatkozik. A barlang falán a túravezetők segítésére 100 méterenként szám van felfestve, ez alapján lehet a területeket azonosítani. Vértes kiszállási jelentése 1960; MNM Adattár XI.247/1961.

44 Vértes kiszállási jelentése 1960; MNM Adattár XI.247/1961.

45 РАTEK 1960.

46 JAKUCS 1960.

47 “Megállapíthattuk, hogy ezen a területen - mint különben az egész barlangban is az őskori anyag mindenütt az agyagra 1-2 cm vastagságban lerakódott koromrétegben fekszik - vagy feküdt - a felszínen.” Vértes kiszállási jelentése 1960; MNM Adattár XI.247/1961 - Ezzel ellentétben a helyszínen csak mm-nél vékonyabb korom réteg fedi az agyagot. Dénes György szóbeli közlése szerint a geológiai kutatóárok létesítése elött a belső terem alkalmas volt táborozásra.

48 Vértes 1953. 
találtuk nyomukat - el lehet fogadni.

Tündérek vára (2240m)

Terepbejáráskor leleteket nem találtunk.

Pisai ferdetorony (2660m)

Terepbejáráskor leleteket nem találtunk.

Matyó rojt (2435m)

A temetkezés tényét már a bejelentéskor vitatták ${ }^{49}$, mi sem tudtunk semmi régészeti bizonyítékot találni annak valódiságára.

Retek-ág

A nyilvánvalóan téves helymeghatározás ${ }^{50}$ Simán Katalin szóbeli közlése alapján valószínüsíthetően a Róka ág, de a Vértes által említett ${ }^{51}$ bemosott csontok elfogadhatók. A járat aktív patakmeder, benne jelen kori bemosott törmelékkel.

Arany utca

Vértes László helyszíni szemléje során bemosott üledéket észlelt, amit mi még azonosítani sem tudtunk a megtelepedésre teljesen alkalmatlan helyen. A 2004-ben, kábel árok ásáskor a rétegsorban sem tapasztaltunk kulturrétegre utaló nyomot.

Óriások-terme

A barlang legnagyobb rejtélye Vass Imre leírásának értelmezése ${ }^{52}$. Semmi nem zárja ki, hogy bármely korban lehetett volna olyan szárazabb időjárási periódus, hogy a barlang végig járható legyen. Vass Imrének is csak három évet kellett várni egy ilyen alkalomra. Korábban a Vaskapu omladéka is lehetett olyan helyzetben hogy ne alakuljon ki állandó tó ott, ahol a későbbi kutatók kénytelenek voltak vissza fordulni. De határozott bizonyossággal nem állíthatjuk, hogy a bejutás régészeti korokban meg is történt. Vass Imre leírásából a fekete korsó darabok csak a barlang többi lelete alapján köthetők a késő bronzkorhoz, és a lábnyomokban lévő vastag cseppkő kéreg sem

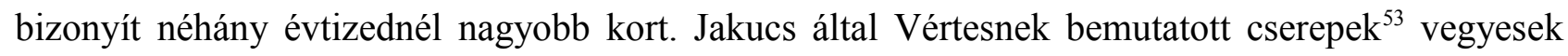
voltak, és Vértes utána átkutatta a területet öt barlangász segítségével, eredménytelenül. Vagy Jakucs összeszedte az összes fellelhető leletet (ami egy omladékos terepen elég nehéz), vagy a bemutatott leletek nem eredeti helyzetükben voltak a teremben. Feltételezések szerint Jakucsot saját kollégái is megviccelhették ilyen leletekkel.

49 Vértes kiszállási jelentése 1960; MNM Adattár XI.247/1961.

50 KÉRDÖ 2000.

51 VÉRTES 1953.

52 VASS 1831, 62.o.; JAKUCS 1960.

53 Vértes kiszállási jelentése 1960; MNM Adattár XI.247/1961. 
Bonyolítja a képet, hogy Salamon Gábor és Grúber Péter szóbeli közlése nyomán, a teljesen lelet mentes teremben két helyen begyüjtöttünk kora-Árpádkori kerámiákat, olyan pozícióban és olyan állapotban, hogy azt se víz nem moshatta be, se szándékos félrevezetésből nem rakhatták ki. A leletek kora azt is kizárja, hogy a barlang egyéb részeiből származhatnának, de még a felszínen sem lehet ilyet találni. Előfordulhat viszont, hogy a leleteket többször is átmozgatták, de még így is rejtély a származási hely.

\section{A barlangi kutatások dokumentálása}

A kutatás történetet vizsgálva meg kell állapítanunk, hogy a legrészletesebb dokumentáció Nyáry Jenőtől származik. Ö pontosan leírta a területek neveit, és térképet közöl a barlangról ${ }^{54}$. Ez a térkép a Vass Imre-féle térkép átrajzolása, tehát előtte és utána is lehetőség lett volna legalább ezt a térképet felhasználni a dokumentáláshoz. Az Archeologiai Értesítő XI. számában ${ }^{55}$ részletesebb helyszínrajzot közölnek, és Nyáry könyvének 158-159. oldalán közölt metszetekből is egyértelműen azonosítható a temetkezési folyosó. Így a legfontosabb ásatási helyet a barlangban azonosítani lehet. Sajnos azonban a könyv tábláin lefestett helyszínek egyáltalán nem egyeztethetők a barlang pontjaival.

Kadić ásatási szelvényét leírás alapján pontosan be lehetett tájolni, Mottl-Vértes-Kordos Denevérági szelvénye ma is látható, ahogy Kordos többi szelvénye is. Rezi Kató Gábor Róka-ági szelvénye se lett vissza temetve, ezért az tanulmányozható. A Hangverseny-terem feltárása elpusztult, és semmilyen dokumentumát nem ismerjük, csak egy fényképet találtunk, amelyen talán azonosítható. A Fekete terem közepén lévő szelvény szép metszetéből valószínüsíthető hogy ásatás volt, de semmilyen dokumentációját nem ismerjük. A Gallus-féle Denevér-ági karólyukas szelvényt ${ }^{56}$ nem sikerült azonosítani, pedig ez a legrészletesebb felszínrajz a barlangból. Csak azt tudhatjuk biztosan, hogy egy ilyen karólyukas rajzhoz le kell takarítani a kulturréteget, ezért a szelvény nem lehet azokon a helyeken, ahol az jelenleg is még érintetlen. Helyszínrajz vázlatot egyedül Vértes 1960-as ásatásának naplójában találtunk ${ }^{57}$, ez alapján be is tudtuk azonosítani a betemetett szelvény helyét. A barlangban folyamatosan történnek lelet gyüjtések és lelet áthalmozások barlangászok által, aminek semmiféle dokumentációja nincs, maximum szóbeli közlésekre lehet hagyatkozni.

\footnotetext{
54 NYÁRY 1881, könyv vége.
}

$55-1877 d$.

56 BANNER 1943.

57 Vértes L. kiszállási jelentése 1960; MNM Adattár XI.247/1961. 


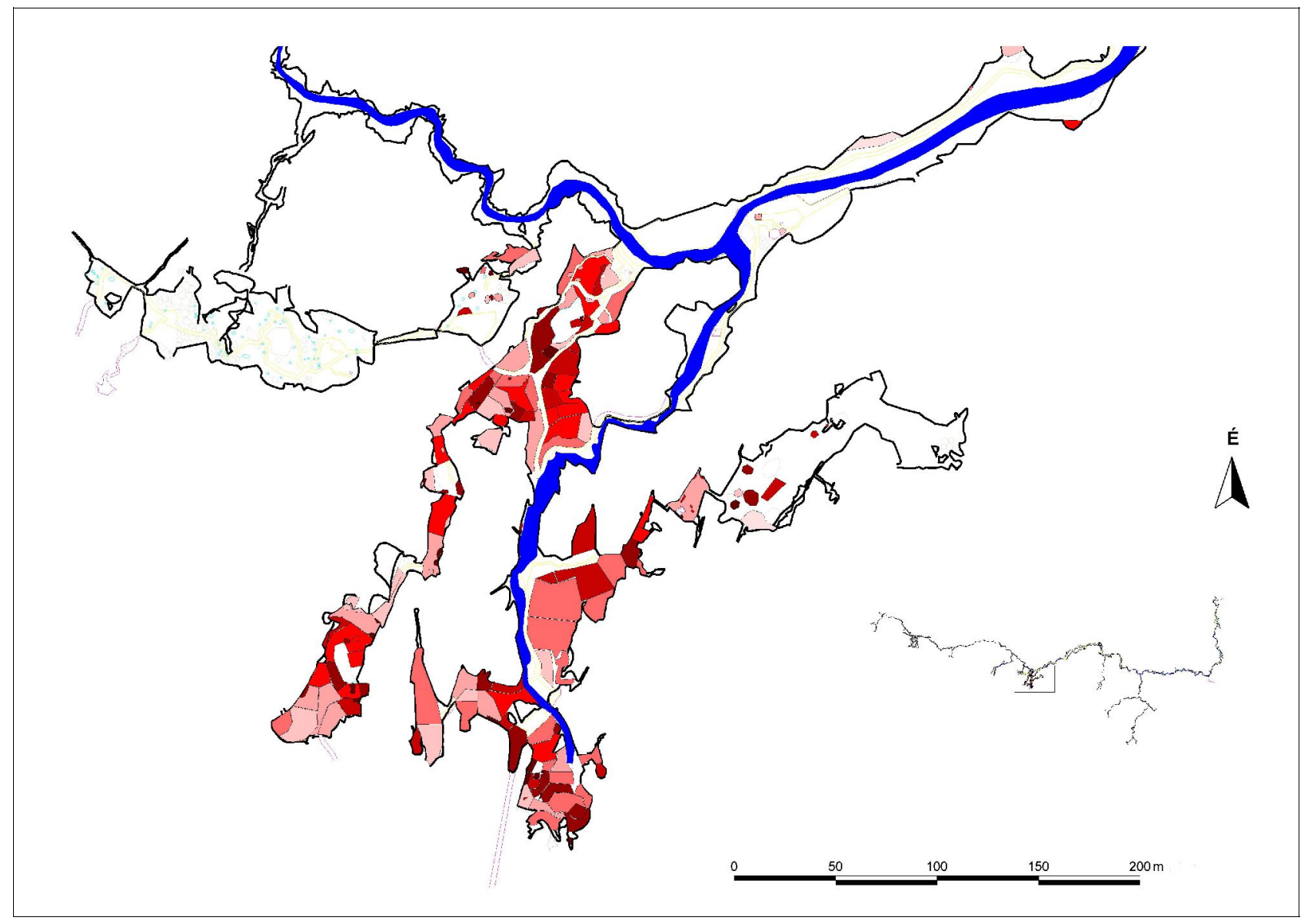

4. kép A leletek eloszlási térképe. A sötétebb szín nagyobb leletsürüséget jelent

Fig.4. The distribution of the finds. The darker colour corresponds to larger find density

\section{A leletek elterjedési térképe}

A barlangban végzett terepbejárás eredményeként pontos statisztikával rendelkezünk a felszíni leletek megoszlásáról. A terepbejárás során felszedtünk minden felszíni leletet és területenként külön csomagoltuk. A területek elhatárolásakor a természetes összefüggő egységeket vettük alapul, így különböző méretü, de egy egységen belül azonos morfológiájú területek lettek egybe gyüjtve. A térinformatikai feldolgozásnál a gyakoriság számításakor a leletszámot elosztottuk a terület méretével. Sajnos a leletek száma nagyon sok tényezőtől függ, és ezek között a régészeti korokban az emberi tevékenység intenzitása csak az egyik tényező. Ezen kívül elsődlegesen a bolygatás (régészeti ásatás vagy müszaki munkálatok), továbbá a látogatók általi áthalmozás jöhet szóba. A teljesen lebetonozott részeken természetesen nem lehet leleteket gyüjteni, de járda építéskor a kiásott kulturréteget oldalra halmozhatták.

Ezért csak nagyon általános következtetéseket lehet levonni, azt is csak óvatosan. 


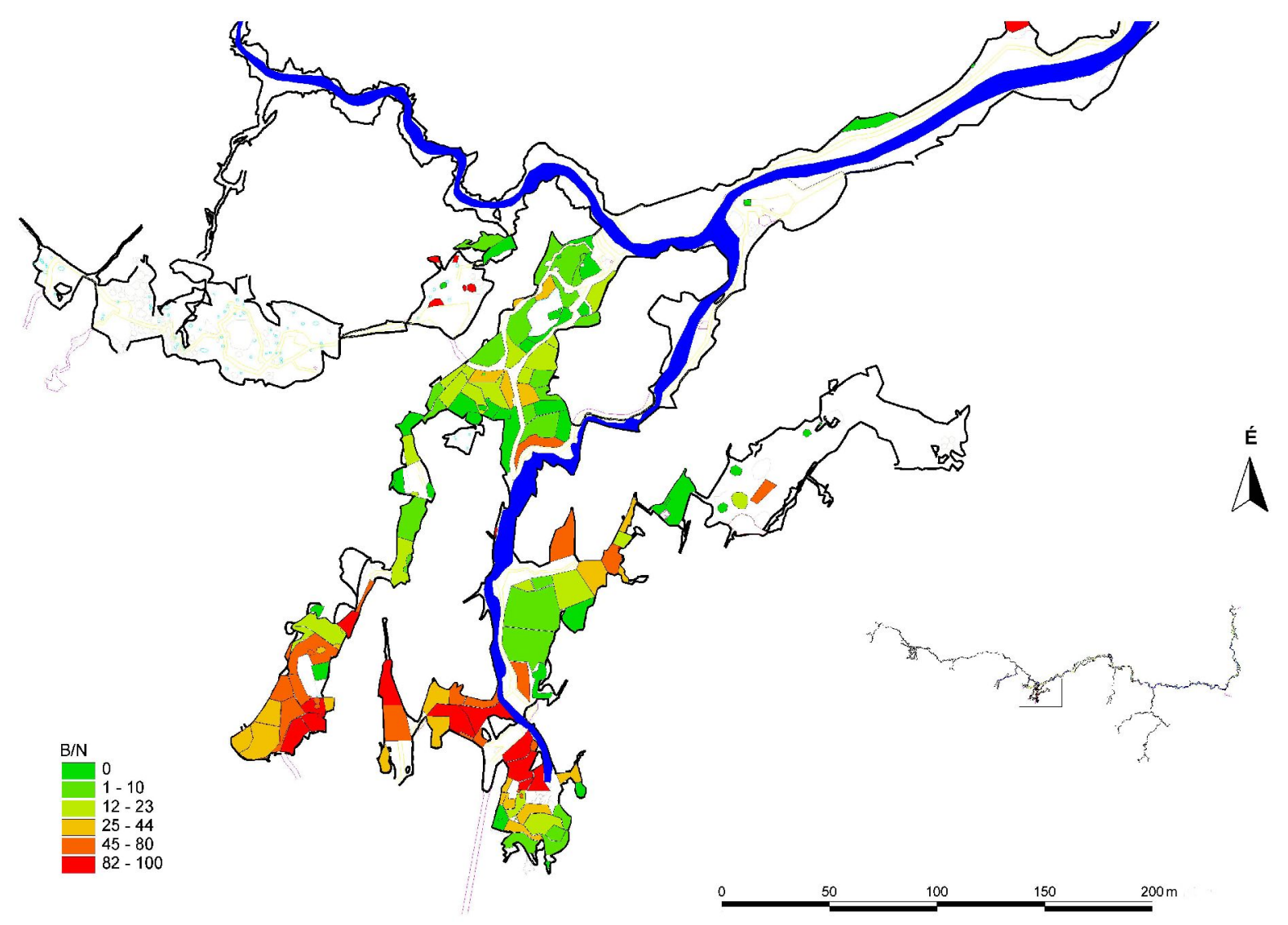

5. kép A neolit - későbronzkor arány a leletsűrüségben. A számok a két korszak közötti százalékos megoszlást jelölik

Fig.5. The neolithic/late bronze age ratio in the density of finds. The numbers represent the percentages of the finds from the two ages

A lelet sürüség a barlang Aggteleki részén, a megfigyelt területeken nem mutat kapcsolatot a bejárattól való távolsággal, inkább az összefüggő leletben gazdag területek szakadoznak fel, majd teljesen lelet mentes területek következnek egy-egy különálló lelettel. Két biztos megállapítást tehetünk: a barlang Csónakázó-tavon túli részét nem használták, és a Róka-ágban nem volt bejárat a neolit kortól kezdve (4. kép).

A leletek korok szerinti megoszlása már egyértelmübb. A neolit - későbronzkor arányt figyelve megállapítható, hogy míg a neolitikumban (Bükki kultúra) a barlang minden pontját egyaránt használták, még a legelképesztőbb helyeket is mint a Cserepes-terem, vagy a Csontház-terem felső omladékos része, addig a későbronzkorban csak a bejáratok környékét (Főbejárat, Denevér-ág), és a barlang simább, tevékenységre alkalmasabb helyeit (5. kép).

A középkori leletek a Föbejárat közvetlen környékén koncentrálódnak (6. kép). 


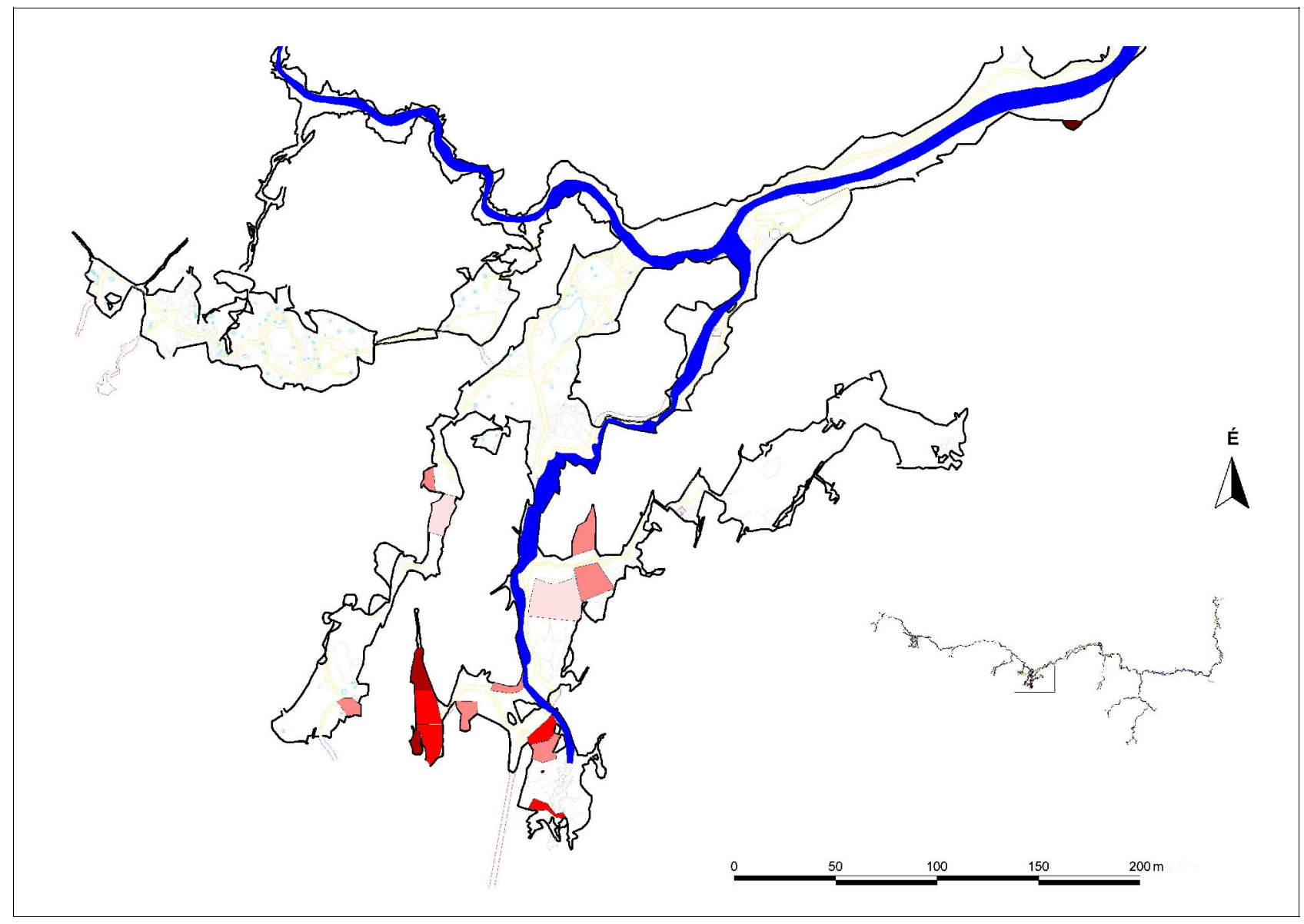

6. kép A középkori leletek eloszlása. A sötétebb szín nagyobb leletsürüséget jelent

Fig.6. The distribution of the medieval finds. The darker colour corresponds to larger density

Ebből azt a következtetést vonhatjuk le, hogy amíg a neolitikumban a barlang „,kultikus” használata szinte biztosra vehető, a bronzkorban sokkal gyakorlatiasabb megfontolások vezették a helyek kiválasztásában az embereket. A neolit víznyerési szükséglet bizonyítható egyes becseppkövesedett edényekkel, a bronzkorban ilyen példákat nem találunk.

A középkori emberek valószínüleg csak látogatók voltak a barlangban, rövid elrejtőzéseket leszámítva, amikor is nem végeztek tevékenységet a barlang belső részeiben.

\section{Régészeti jelenségek a barlangban}

A barlangban kulturrétegeket, tüzelés nyomokat, karólyukakat (cölöplyukakat), temetkezéseket, in situ edényeket és korom rétegeket figyelhetünk meg. Ezek területi eloszlása egyenletes az aggteleki részen. Karólyukakat például minden kulturréteg metszetben felfedezhetünk, gyanítható hogy a faszenes, cserepes réteg eltávolításával mindenütt kirajzolódnának a Gallus-féle felszínrajzhoz hasonló, értelmezhetetlen mintázatok. A sokféle magyarázat, amit a szakirodalom közöl, mind 
kétségeket ébreszt. Itt kell megjegyeznünk, hogy kellő barlangász tapasztalatok nélkül a régész könnyen jut helytelen következtetésekre. A barlangban se szél, se eső, se fagy nem nehezíti a táborozást, így fedelet vagy szélfogót nem érdemes készíteni. A csepegő víz kifejezetten hasznos víznyerésre, csak nem szabad alá feküdni. A tüzet nem veszélyezteti a csepegés és a huzat, nem kell védeni. Nem is találtunk épített tüzhely nyomát, csak tüzelésnyomokat a szabad agyag felszíneken. Fekhelynek a felhalmozott széna, és állatbőrök kiválóan alkalmasak, nem kifizetődő földbe szúrt karók közé ágyat kifeszíteni. A karólyukak magyarázatául két feltevést lehet elfogadni. A barlangban tartott állatok elrekesztését szolgáló kerítés karóinak nyoma. A kerítést rendszeresen megújítottak és helyét megváltoztattak. A másik a fáklyák nyelének leszúrása a puha agyagba, hogy el ne dőljön, és kellőképpen bevilágítsa a területet ${ }^{58}$. A fáklyákból sok fogyott, és leszúrásuk rendszer nélkül történt, így rövid idő alatt is létrejöhetett az a rengeteg karónyom, ami egy-egy felszínen megfigyelhető.

A tüzelés nyomok egyértelműen felismerhetők. A tapasztás és felépítmény nélküli tűzhelyeket a természetes agyagfelszín átégése mutatja. Ha nincs alatta vagy felette kulturréteg, koruk nehezen határozható meg. Feltételezhető, hogy arra alkalmas helyeken különböző korokban többször is megismétlődött a tüzrakás. A tüz kellemetlen velejárója a füst, főleg ha a barlangban tárolt, átnyirkosodott tüzelő anyagot használtak. Ezért tüzet rakni, tüz körül táborozni csak kellő nagyságú, szellőzött légtérben lehet. A füstből lerakódó korom megfigyelhető a cseppkő rétegek belsejében, de leginkább a huzat irányára következtethetünk az elhelyezkedéséből. A Csónakázó-tó vége felé megfigyelhető korom csíkos cseppkő rétegek környékén egyáltalán nem találhatók leletek, a füstöt a Hangverseny-teremből vihette oda a légáramlás.

Temetkezéseket Nyáry Jenő a Pitvart a Csontház-teremmel összekötő folyosóban tárt fel. Ezek dokumentációjából azt meg lehet állapítani, hogy szabályos temetkezés volt, bár a megmaradt csontok (7. kép) alapján elég kis mélységü. Tompa Ferenc a Csontház-teremben és a Róka-ág elején említ temetkezést. A bejárat közelében, a Kéménynél megbolygattak temetkezéseket. Jakucs László a Matyórojt közelében említ egy cseppkő medencében lévő, kővel letakart gyermeksírt. Ennek valódisága megkérdőjelezhető, de hasonló (cseppkő medencében szabadon lévő) csontvázat neolit melléklettel mi is felderítettünk a Hangverseny-terem melletti Óriáscseppkövön. Megállapítható, hogy több helyen, több korban különböző temetkezések voltak a barlangban. Mivel a Korek József bejárat elött is feltárt neolit temetkezést, nem tekinthetjük a barlangot kizárólagosan temetkezési helynek.

58 Mint ezt a Norbet Casteret által felfedezett Montespani-barlangban is megállapították. N. Casteret: Harminc év a föld alatt. Budapest. 1962, 11.o. 


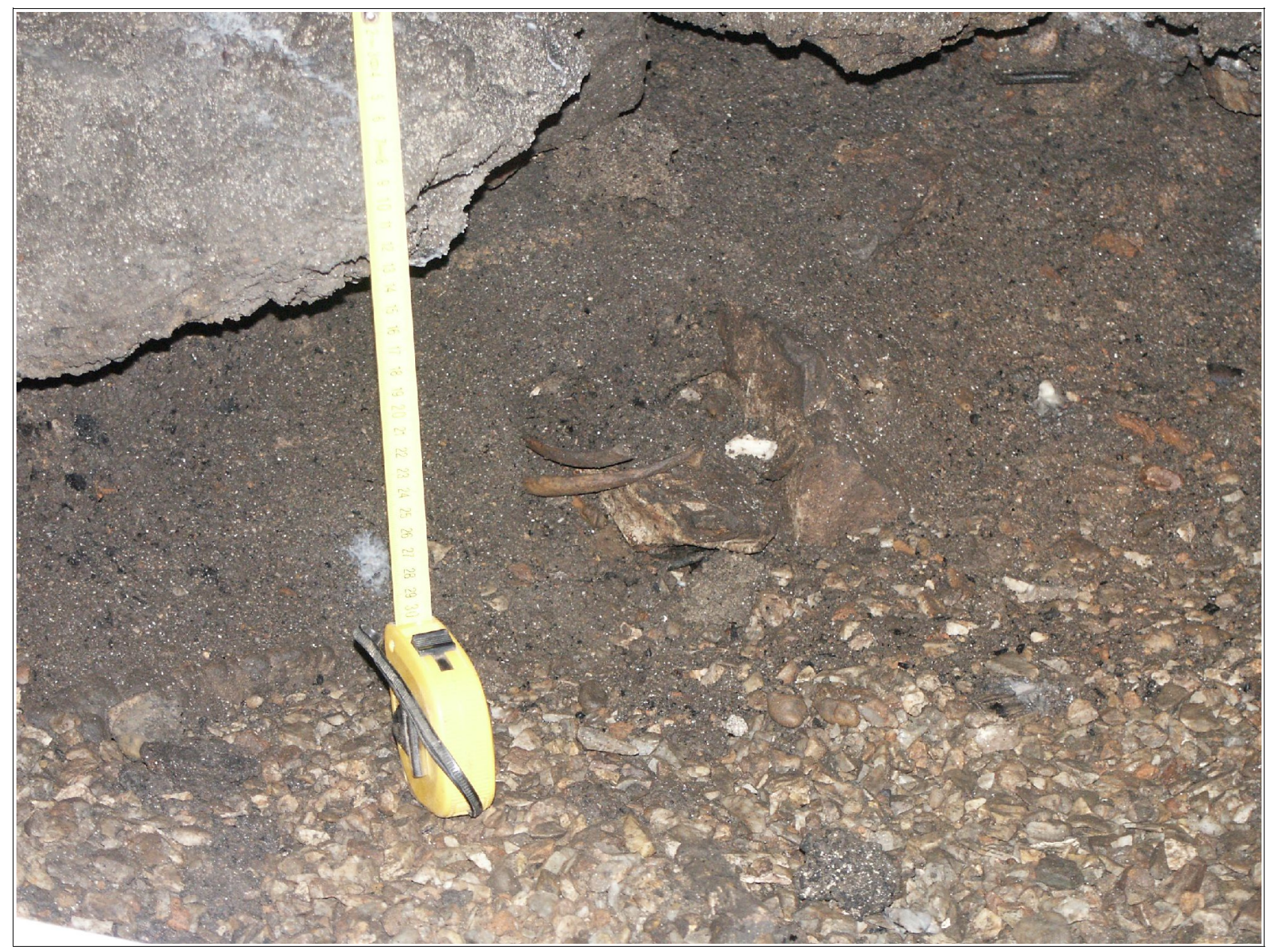

7. kép Csontok a cseppkőkéreg alatti rétegben

Fig.7. Bones in the layer beneath the dripstone layer

Edényeket eredeti helyzetben becseppkövesedve, csepegési pontok alatt többnyire töredékesen lehet felfedezni, de egy ponton a Róka-ágban kövek alatt sértetlenül vészelte át a neolitikum óta eltelt időt (8. kép) . Kisebb sérülése ügyetlen kivételi kísérletre utal. A Domicai barlangszakaszban szintén van egy híres, sokszor fényképezett hasonló edény. Ezek az edények közvetlen bizonyítékai a barlangi vízgyüjtésnek a neolitikumban. Későbronzkori ilyen leletet nem ismerünk. A Csontházteremben egy ponton olyan hasadékba becsúszott és odacseppkövesedett edényeket lehet látni, ami biztosan nem szándékos elhelyezés, csak a környék használatára utal.

A kulturrétegek, mint azt Vértes is megállapította ${ }^{59}$, az agyag felszínen néhány centiméter vastagságban elhelyezkedő cserepekkel, csontokkal vegyes, fekete üledék. Csekély vastagsága, és a záró rétegek hiánya miatt korokra nem bontható, néhány szerencsés kivételtől eltekintve, amikor is omlás vagy cseppkő bekérgezés kerül közé vagy rá. Legtöbbször a felszínről gyüjthetők a neolit kerámia darabok, mivel a leletek mérete nagyobb mint a réteg vastagsága.

59 Vértes kiszállási jelentése 1960; MNM Adattár XI. 247/1961 


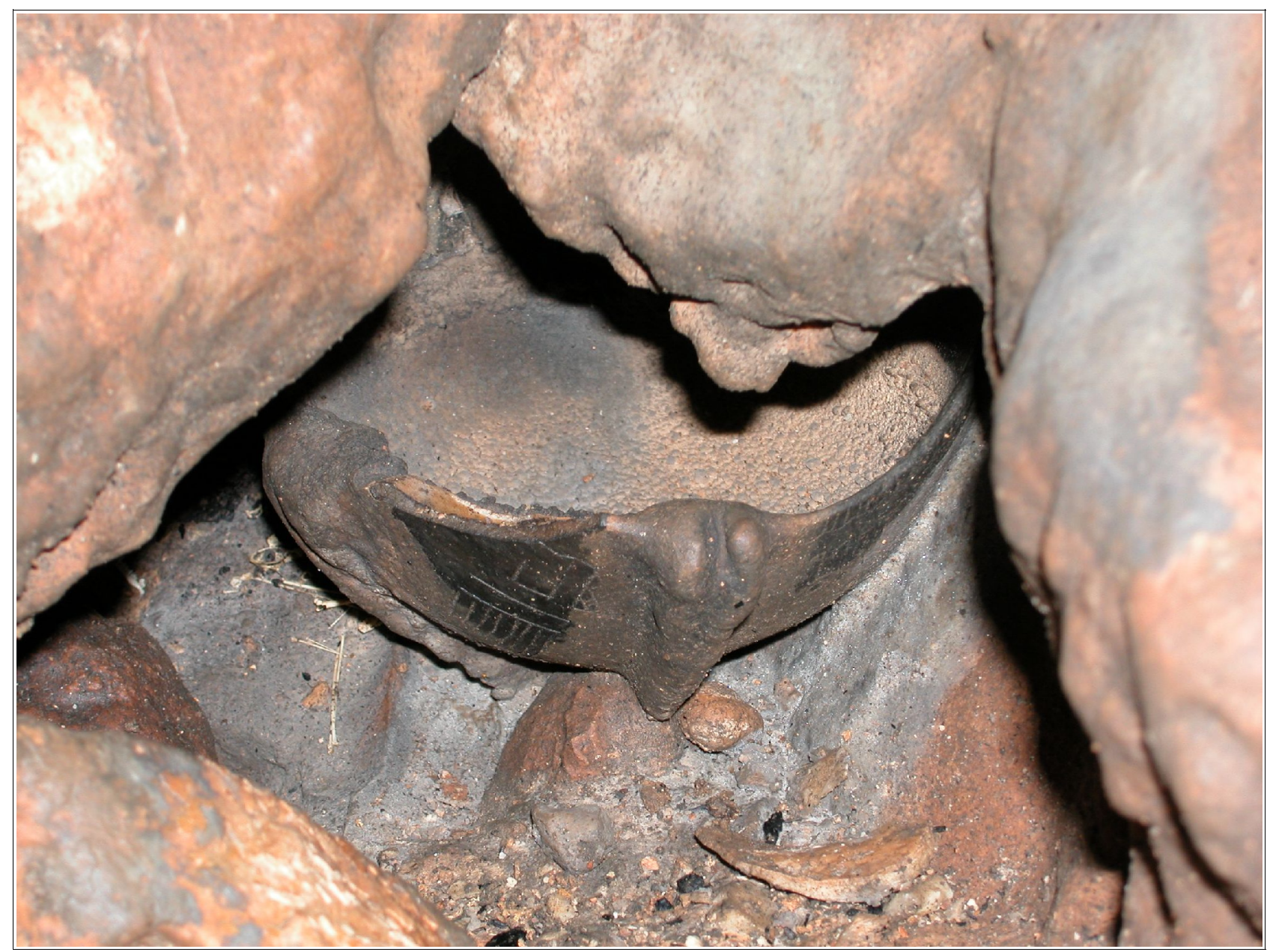

8. kép Becseppkövesedett neolit edény a Róka-ágban

Fig.8. Neolithic vessel covered with dripstone from the Roka-branch

Megállapíthatjuk, hogy a felszíni lelőhelyek jelenségeihez képest a Baradla-barlang régészeti jelenségei (több más barlanghoz hasonlóan) merőben más képet mutatnak, kutatásuk, dokumentálásuk más technikát igényel. 


\section{A BARADLA BARLANG VÁLOGATOTT RÉGÉSZETI IRODALMA}

1876a Az aggteleki barlang. VU Okt. 15.Szept 10, 588, 605, 688

1876b A m. történelmi társulat ezévi gömörmegyei kirándulása. ArchÉrt X, 288-289.

1876c Az aggteleki barlang újabb ásatásáról. ArchÉrt X, 335.

1877a Az aggteleki barlang. VU 540.

1877b Az aggteleki barlangban talált őskoponyákról. ArchÉrt XI, 98.

1877c Az aggteleki barlangban lelt ös növénymagvak és csontok. ArchÉrt XI, 132.

1877d A legújabb aggteleki ásatások. ArchÉrt XI, 268-269.

1912a Jelentés a Magyar Nemzeti Múzeum 1911 évi állapotáról, Régiségtár - Éremtár. Budapest. MNM, 35-36.

1912b A Magyarhoni Földtani Társulat Barlangkutató bizottságának 1911.-évi jelentése. Ftk XLII/3, 461464.

1862 A Domicza Barlang. VU, 136-137.

1863 Az aggteleki barlang. VU, 284-285, 291-293.

1878 Külföldi érdeklődés a hazai régészet iránt. ArchÉrt XII, 127.

1911 Jelentés a Magyar Nemzeti Múzeum 1910 évi állapotáról, Régiségtár - Éremtár. Budapest. MNM, 3334.

1937 Újabb leletek a Denevérági bejárat áttörésénél. Turisták Lapja 49, 256.

1981 Baradla barlang. Beszámoló az MKBT 1981-es munkájáról, 9.

Almási Balogh P.

1820 Baradlai utazás 1818. eszt.-ben. Tudományos Gyüjtemény I, 63-90.

BÁCSKAY E.

1976 Early neolithic chipped stone implements in Hungary. Budapest, Régészeti Dolgozatok II/4. 
Balázs B.

1907 A tibolddaróci bércuti őstelep. ArchÉrt III, 247-266.

BANNER J.

1943 Az újabb kőkori lakóház kutatások mai állása Magyarországon. ArchÉrt 4, 10-11.

1960 A magyarországi újkőkori kutatás néhány kérdéséről. Régészeti Dolgozatok 2, 15-31.

DE BAY J.

1876 Bulletin Monumental, IV, 724.

Bella L.

1912 Újabb hazai barlangkutatások. ArchÉrt XXXII, 358.

Bӧнм J.

1932 Das Leben des Steinzeitmenschen. Die neuesten Funde in der Domica-Höhle. Prager Presse, 27.

Borka Zs.

1979 Paleontológiai vizsgálatok a Baradla-barlangban és környékén. Aggteleki Nemzeti Park.

BOTTYÁn Á.

1955 Szkíták a magyar Alföldön. RégFüz I,

Clementis

1818 Baradla barlang bővebb leírása, Tudományos Gyüjtemény, IV, 90-95.

Csalog J.

1941 A magyarországi újabb-kőkori agyagmüvesség bükki és tiszai csoportja. FolArch 3-4, 8-9.

1955 A tiszai müveltség viszonya a szomszédos újkőkori müveltségekhez. FolArch 7, 24.

1976 Az újkőkorszak embere A magyar régészet regénye. Panoráma, Budapest, 40-69.

Csalogovits J.

1930 Földrajzi Tényezők hatása Magyarország neolitikus kultúráinak kialakulására és elterjedésére. ArchÉrt XLIV, 28-52.

CSengeri P.

2001 A bükki kultúra temetkezése Mezőzomboron. Ösrégészeti levelek 3, 12-16.

Csetneki Jelenik E.

1878 Az ősrégészeti kiállítás. ArchÉrt XII, 79.

CZAJLIK Z.

1998 A Baradla és az őskori régészet In: Baross G. (szerk): Az Aggteleki Nemzeti Park. Budapest, 223224.

DEÁK F.

1876 Jelentés a kutatások eredményiről. III. Az aggteleki barlangban tett ásatásokról.

A Magy. Tört. Társ. 1876-ik évi aug. 21-28-iki vidéki kirándulása Gömörmegyébe, 56-57.

DéNEs Gy.

1978 Régészeti leletek az aggteleki-karsztvidéken és észak-borsodban. Meteor évkönyv, 71-74

Domokos - LiANE-Franz - LeONHARD

1925 Zur Bükker Kultur, WPZ 12, 85-86.

Droppa A.

1961 Domica - Baradla jaskyne prehistorického cloveka Domica - Baradla, az ősember barlangja. 
Sport SV, Pozsony, 106-128.

Dudich E.

1930 Az aggteleki barlang. Ttk 385-397 (395-396).

1932 Az aggteleki cseppkőbarlang és környéke. Budapest, 186.

Foltiny S.

1969 The Hungarian archeological collection of the American Museum of Natural History in New York. Bloomington, 77, 140.

GÁdor J. - Hellebrandt M.

1975 A Herman Ottó Múzeum 1973-1974. évi ásatásai és leletmentései. HOMÉ 13-14, 135.

1976 A Herman Ottó Múzeum ásatásai és leletmentései 1975-ban. HOMÉ 15, 71.

1977 A Herman Ottó Múzeum ásatásai és leletmentései 1976-ban. HOMÉ 16, 77-78.

GÁdor J. - Hellebrandt M. - SimÁn K.

1979 Aggtelek, A Herman Ottó Múzeum 1977-1978. évi ásatásai és leletmentései. HOMÉ, 17-18, 103.

Greguss P.

1940 Prehistorikus faszénmaradványok az aggteleki cseppkőbarlangból. Botanikai Közlemények 2, 288290.

Helebrandt M.

1999 A Bódva-völgy története az őskor utolsó évezredében.

In: Bodnár-Rémiás(szerk):Tanulmányok a Bódva-völgye múltjából. Putnok.

1991 A Herman Ottó Múzeum ásatásai és leletmentései 1988-1990, HOMÉ XXVIII-XXIX, 661-662.

Henszlmann I.

1876 VIII. kongresszus Budapesti ülései. ArchÉrt X, 262.

Hillebrand J.

1913 Az aggteleki Baradla-barlangból újabban kikerült anthropológiai anyag ismertetése. MNM Néprajzi Értesítő, 331-334.

Hunfalvy J.

1867 Gömör és Kishont leírása 1867.

JAKUCS L.

1957 Aggtelek és vidéke útikalauz. Sport, 89-95, 241-242.

1959 Aggtelek (Aggteleki képeskönyv). IBUSZ

1959 Feltünő kutatási eredmények Aggteleken. Karszt és Barlangkutatási Tájékoztató. 1959 dec.

1960 Az aggteleki lábnyomrejtély. Borsodi Szemle I-II, 80-89.

1961 Aggtelek és környéke útikalauza. Sport 94-100, 105.

1962 A faggyúfáklyás expedíció. Sport.

1975 Aggtelek.

1975 A Baradla történelem elötti lakói. Az aggteleki rövid túra. Aggteleki karsztvidék útikalauz. Sport, Budapest, 111-121.

1984 Az aggteleki Baradla-Domica-barlangrendszer. Kordos L.(szerk): Magyarország barlangjai. Budapest, 88-93.

K. VÉGH K. 
1975 Régészeti adatok Észak-Magyarország i. sz. I-IV. századi történetéhez. HOMÉ 13-14, 68, 105.

KAÁN K.

1932 Természetvédelem és a természeti emlékek. 224-225.

KAdić O.

1911 Jelentés az aggteleki Baradla barlangban 1910-ben végzett rendszeres ásatásokról. FtK 41, 665-668, 712-716.

1913 Jelentés a Barlangkutató Bizottságnak 1912 évi müködéséről. Barlangkutatás, I/2, 68-69.

1929 Adatok a magyar barlangkutatás történetéhez. A Természet, 23-24.

1933 A magyar barlangkutatás állása az 1929 évben. Barlangvilág III/3-4, 17-18.

1935 Barlangkutatásaim 1926-ban. Földtani Intézet évi jelentése 1925-28-ról, 191-195.

1938 A magyar barlangkutatás állása az 1937 évben. Barlangvilág VIII/1-2, 11-16.

1941 A magyar barlangkutatás állása az 1940 évben. Barlangvilág XI/1-4, 13-19.

KaLicZ N.

1970 Agyag istenek. A neolitikum és a rézkor emlékei Magyarországon. Budapest.

KaLicz N. - MaKKAY J.

1972 Gefässe mit Gesichtsdarstellungen der Linienbandkeramik in Ungarn. Wien, 9-15.

1973 Gefäße mit Gesichtdarstellungen der Linienbandkeramik in Ungarn Prähistorische Idolkunst. München, 14, 15, 50, 51.

1977 Die Linienbandkeramik in der Grossen Ungarischen Tiefebene.

StudArch VII, 15, 43, 47, 63, 66-67, 71-74, 81, 83, 98, 101, 102, 118, 119, 189, 369, 382.

KaLicz N. - S. Koós J.

2000 Újkőkori arcos edények a Kárpát-medence északkeleti részéből. HOMÉ 39, 15-44.

KemencZei T. - VÉGH K.

1968 A Herman Ottó Múzeum ásatásai és leletmentései 1966-ban. HOMÉ 7, 391.

Kemenczei T.

1967 Az 1966. év régészeti kutatásai, Aggtelek. RégFüz I/20, 5.

1969 Új régészeti leletek az aggteleki Baradla-barlangból. MHOMK 8, 1-6.

1970 A Kyjatice kultúra Észak Magyarországon. HOMÉ 9, 27, 78.

1984 Die Spätbronzezeit Nordostungarns. Budapest, ArchHung LI, 26, 41-43, 45-48, 51, 56, 127-128, 144.

KÉRDÖ K.

2000 A község környékének régészeti emlékei. In: Jósvafö - település a források és barlangok völgyében. MicroPress, Jósvafö, 41-48.

KessLer H.

1934 A Nagy-Baradla. (magán kiadás) 28-30, 35.

1937 A Nemzeti Múzeum ásatásai. Turisták Lapja július, 49, 299-300.

1937 Az Aggtelek-Jósvafői "BARADLA" cseppkőbarlang ÉRTESÍTŐJE. A jövő év tervei. Turisták Lapja november, 413.

1940 Az ősélet újabb nyomai az aggteleki cseppkőbarlangban. TtK, 176-178.

Kessler H. - MozsÁri G.

1985 Barlangok útjain, vizein. Budapest. 
Kordos L.

1975 Az Aggteleki-karszt szubfosszilis gerinces faunáinak állatföldrajzi és ökológiai vizsgálata. MÁFI adattár T.6094,

1976 Barlangi gerinces őslénytani ásatások és gyüjtések 1976-ban. MÁFI adattár T.6842, 1-23.

1976 Jelentés az Öslénytani Szakbizottság 1976. évi munkájáról.

Beszámoló az MKBT 1976-os munkájáról. 34.

1976 Barlangi őslénytani ásatások és gyüjtések 1976-ben.

Beszámoló az MKBT 1976-es munkájáról. 36-38.

1977 Barlangi öslénytani ásatások és gyüjtések 1977-ben.

Beszámoló az MKBT 1977-es munkájáról. 15.

1982 Evolution of the Holocene Verebrate Fauna in the Carpathian Basin. Berlin, Zeitschrift für Geologische Wissenschaften 10,963-970.

KoreK J.

1958 A bükki kultúra települése a Hillebrand barlangban. FolArch 10, 21-22.

1959 Zu den anthropomorphen Darstellungen der Bükker-Kultur. FolArch 11, 20.

1969a Újkőkori telepek és sírok Aggteleken. Karszt és Barlang 1, 39-40.

1969b Újkőkori telep és sírok Aggteleken. Karszt- és Barlangkutatási Tájékoztató 1-2.

1970a Aggtelek. ArchÉrt 97, 304

1970b Nyíltszíni bükki telep és sírok Aggteleken. ArchÉrt 97, 3-22.

1970c Az 1969. év régészeti kutatásai, Aggtelek. RégFüz I/23, 3.

1972 Katalog der angestellen Funde. Wien, 14, 31-44.

Korek J. - Patay P.

1958 A bükki kultúra elterjedése Magyarországon. RégFüz II/2, 19-21.

Kossuth L.

1882 Tanulmányok Báró Nyáry Jenő >Az aggteleki barlang, mint őskori temető< czímü munkája felett. ArchÉrt 16, 167-206.

1883 Tanulmányok Báró Nyáry Jenő >Az aggteleki barlang, mint őskori temető< czímü munkája felett. PN, 55-57, 59-63, 65.

LEHOCZKY T.

1898 Öskori örlő kövekről. ArchÉrt XVIII, 89-90.

LESZIH A.

1927 A Miskolci Múzeum ásatásai Borsodon. Történeti és Régészeti közlemények II/1, 85-94.

MÁrton L.

1911 Jelentés a Magyar Nemzeti Múzeum 1910 évi állapotáról.

Dr. Márton Lajos segédőr jelentése az aggteleki barlangi ásatásról. MNM, 196-199.

1912 Die wichtigsten Resultate vor- und frühgeschichtlicher Forsung in Ungarn. PZ 3, 178-191.

MiLetz

1876 Aggteleki barlangban végzett ásatások, Temesvár. Történelmi és Régészeti Értesítő II, 213.

MotтL M.

1940 Jelentés az 1940. évi földtani intézeti őslénytani kutatásokról és ásatásokról, MÁFI adattár 
T.5525, T.1409/23, 1-3.

Mozsolics A.

1985 Bronzefunde aus Ungarn / Depotfundhorizonte von Aranyos, Kurd und Gyermely. Budapest, 94-95.

NYÁRY J.

1877 Les hommes de l'age de la pierre dans la caverne d'Aggtelek, Compté de Gömör Compte Rendu de la huitieme session, Budapest 1876. Budapest, I, 626-634.

1881 Az aggteleki barlang, mint őskori temető. Budapest.

Ország Gy. - Vid Ö. - Szilágyi F. - Végh Zs. - Gyuricza Gy.

1989 Magyarország Barlangtérképei 7. Baradla-barlang. Budapest.

P. Hartyáni B. - NovÁKi Gy.

1975 Samen- und Früchtfunde in Ungarn vonder Neusteinzeit bis zum 18. Jahrhundert.

Agrártörténeti Szemle, XVII suppl, 20-23.

PÁRDUCZ M.

1967 Ásatási jelentések ... 1949, ArchÉrt 76, 111-112.

PATEK E.

1960 Az 1959 év régészeti kutatásai, RégFüz II/13, 31-32.

РетHÖ T.

1966 Budapest - Miskolc - Aggtelek. Panoráma, Budapest, Magyarország írásban és képben, 5, 121.

1976 Füttyentő nyúl a Csontház-teremből. Miskolc, Észak-Magyarország XXXII, 93.

RAISZ G. - SiEgMETH K.

1890 Az aggteleki cseppkőbarlang, Eperjes.

RAISZ K.

1807 Topographische Beschreibung der im Gömörer Comitate bei dem Dorfe Aktelek befindlichen Höhle Baradla In: Beredetzky S.: Neue Beytrage zur Topographie und Satistik des Königreichs Ungarn. Wien.

Rezi Kató G.

1997 RégFüz II/48, 5.

2003 Régészeti Kutatások Magyarországon 2001-Aggtelek, Baradla-barlang. KÖH-MNM, Budapest 133.

2004 Régészeti Kutatások Magyarországon 2002- Miskolc, Baradla-barlang. KÖH-MNM, Budapest 241242 .

RIEDL G.

1914 Hillebrand Jenő: Az aggteleki Baradla-barlang. Barlangkutatás II/2, 87-88.

SCHMIDL A.

1857 Die Baradla-Höhle bei Aggtelek und die Lednica-Eishöhle bei Szilitze in Gömör Comitate Ungarns, Wien, 13, 14, 17, 18, 41, 42.

Schwab E.

1865 Land und Leute in Ungarn, Lipcse,

SIEGMETH K.

1886 Die Arbeiten in der Aggteleker Höhle, Mittheilungen der Sektion für Höhlenkunde des Österr. Touristen-Club 
1890 Az Aggteleki barlang. 142-147.

1898 Notes sur les cavernes de Hongrie. Mémorie de la Société de Spéléologie III, 147-164.

1910 Az Aggteleki barlang. Kassa, 8-9.

SimÁn K.

1982 Aggtelek-Baradla barlang. HOMÉ XXI, 110.

Spötтl I.

1882 Prähistorisches aus Ungarn. MAG, 96-97

Staub M.

1882 Prähistorisches Pflanzen aus Ungarn. Englers Botanische Jahrbücher, 281-287.

STRÖMPL G.

1922 A Gömör-Tornai karszt emberi telepei. Szeged, Föld és Ember, 1-7.

SZÉKELY K.

2005 Baradla-barlang. Aggtelek.

SzEnDReI $\mathbf{J}$.

1884 Hazai adatok az archeológiához. ArchÉrt III, 109-137.

SZUKÁts J.

1877 Az aggteleki legújabb ásatások. Fővárosi lapok, 190.

TÉGLÁS G.

1882 Az aggteleki barlang ősembertani jelentősége. Budapesti Szemle 29, 39-53.

Teleki D.

1796 Egynéhány hazai utazások leírása Tót- és Horváthországoknak esmertetésével egygyütt. Béts, 37-39.

Tempír Z

1964 Beitäge zur ältesten Geschichte des Pflanzenbaus in Ungarn. ActaArchHung XVI, 65-98.

Tомен F.

1929 A Nemzeti Múzeum ásatásai az aggteleki Baradla-barlangban. Magyarság.

1929 Die Bandkeramik in Ungarn. Budapest, ArchHung, 5-6, 12-13, 14, 19-20, 27, 50.

193525 Jahre Urgeschichtsforschung in Ungarn. Frankfurt, BRGK, 24/25, 34, 37-38, 10t 1-2, 11t 1-14, 1$2 \mathrm{k}$.

1937 Adatok az őskori aranykereskedelemhez. ArchÉrt 50, 52-54.

1938 Öskori gyűjtemény. Vezető a régészeti gyüjteményben. Budapest, 10.

То́тн E.

2004 Bükki kerámiaedény restaurálása. HOMÉ, 685-690.

VAss I.

1831 Az Aggteleki barlang leírása. Landerrer, Pest.

1987 Az Aggteleki barlang leírása. Érc és Ásványbányászati Múzeum, Rudabánya, Reprint

VÉRTES L.

1945 Aggtelek. Magyar Ifjúság, szept.

1952 Az aggteleki barlang, mint az ősember lakóhelye. In: Jakucs László: Aggteleki cseppkőbarlang, Müvelt Nép, Budapest, 30-32.

1953 A Baradla barlang ősrégészeti kérdéseiről. Hidrológiai Közlöny 33, 71-72. 
1954 Néhány új őskori lelőhelyünkről. FolArch 6, 17-19.

1955 Leletmentő ásatások az 1953. évben. ArchÉrt 82/1, 96.

1959 Untersuchung an Höhlensedimenten. RégFüz II/7, 115-116.

1965 Az őskőkor és az átmeneti kőkor emlékei Magyarországon. Budapest, 90, 227.

VIRCHOW R.

1877 Die Bärenhöhle von Aggtelek in Ober-Ungarn. ZfE, 310-327.

WILKE G.

1924 Baradla-Höhle. ERV I, 347-348.

ZIсHY I.

Jelentés az Országos Magyar Történeti Múzeum 1937.-évi állapotáról és működéséről. Budapest, 31.

\title{
ARCHEOLOGICAL SURVEY OF THE BARADLA CAVE
}

\author{
BALÁZS HOLL
}

The Baradla was the first cave to be examined archeologically in Hungary, yet it is not fully documented still. We will attempt to construct the archeological topography of the cave, collecting the data from previous studies and from our own survey. The data from the literature contains several misinterpretations according to our in situ examinations, because the authors has limited or incorrect information on the speleological circumstances. The cave is an important archeological site compared to the sites on the surface, and other neighboring caves. The only archeological site known on the surface is at the Aggtelek entrance, and the Domica and Ordog-lyuk (Certova diera) are the known caves with archeological finds. The Baradla Cave System is a hydrologically continuous unit from the Domica cave in Slovakia to Josvafo, but the archeological site can only be associated with Aggtelek, because the Josvafo entrance was opened only recently, and the connection with Domica is hardly passable, at same places only underwater connections exists. There is a clear logical connection to the neolithic site at the Domica, but these are separate sites the distance is $2 \mathrm{~km}$. The strong erosion of the karstic surface makes the archeological sites in the caves more important - nothing is preserved on the surface. The finds are usually washed down to a cave, but that can not be considered an archeological site in a cave. In the smaller caves the strata and other phenomena could be easily damaged because of an improper excavation. In the Baradla Cave the strata and other phenomena are intact on large areas. The cave is located at the Aggtelek karstic region. There are only temporary lakes and streams close to the Aggtelek entrance. Secular changes in the climate or the geomorphology (as filling up of the gullies) could result in different surface hydrological situations after a few centuries. This obviously affects the habitability of the region. We consider the water systems in the caves more stable. 